\title{
Arrows Can Be Dangerous
}

\author{
J ohn Monk
}

\author{
Communications and Systems, Open University, UK, johmonk@gmail.com
}

\begin{abstract}
Arrow signs find use in professional fields and are a part of everyday practices. The application of arrow signs in scientific literature is briefly explored. A fragment of the arrow's cultural history is outlined and identification of a family of arrow shapes confirms that arrow signs do not have a unique form. The broad arrow is introduced as a sign that has been used in disparate practices, illustrating that signs are embedded in social networks and showing a sign cannot be said to have a unique meaning and is informative or meaningful only when it has a role in a socio-technological system. Within a system a sign acts as a catalyst for a variety of relationships. To unravel some of those relationships an analytical framework proposed by Jakobson is applied to a variety of arrow signs. Jakobson's functional categories show that practices incorporating signs are not under the control of the sign maker and occasionally a change in a sign's use can transform an acceptable sign into one that provokes anger or brings ignominy. Such negative effects draw attention to the ethical dimension of signs, or rather the ethics of the practices that encompass signs.
\end{abstract}

Keywords: Arrow signs, Semiotics, Poetics, Broad Arrow, English Law, Ethics

A familiar element of many signs is an image of an arrow. Signs incorporating arrow images are material artefacts that are intended to influence what people do, and a reaction to an arrow sign by a sign reader is both a product of a social convention that guides the reader's specific response and a defining statement that sustains or alters a customary practice. Where sign readers respond we are inclined to say the sign is informative and conveys information, but a sign may fail to be informative if it does not gain the attention of a sign user, if the sign reader is unfamiliar with the conventions and practices assumed by the sign makers or if the sign reader has scant regard for the authority that the sign projects. Therefore, when sign makers want to create a new sign, they must attend to a sign's saliency and the authority the sign displays but they must also establish a practice that incorporates the sign; a more practical option is to appropriate an artefact, such as the arrow, or image of an artefact that already has a customary use and recognisable qualities that, like a successful literary metaphor, catches on in a new context and has a desired effect on sign readers.

In the Philosophical Investigations Wittgenstein (1992, §454) sketched a picture of an arrow and asked "How does it come about that this arrow points?" He also posed the question so it could be applied to any sign, asking, "Doesn't it seem to carry something in it besides itself?" and continued, "The arrow points only in the application that a living being makes of it". Put another way, a picture of an arrow can be taken as a sign, but what it signifies, what information it provides, what actions it elicits are dependent on the individuals who encounter the arrow image and their customs and habits.

An effective sign, like language, requires established habitual use that aligns the sign makers' expectations with the reaction the sign provokes. Consequently, the sign's use is part of a prevailing tradition that helps to define a community of practice. To enter a coterie formed by, for example, chemists, engineers, painters or road users, individuals develop characteristic habitual uses of signs, often including arrow images, by informally mimicking others and experimenting or by undertaking a formalised apprenticeship.
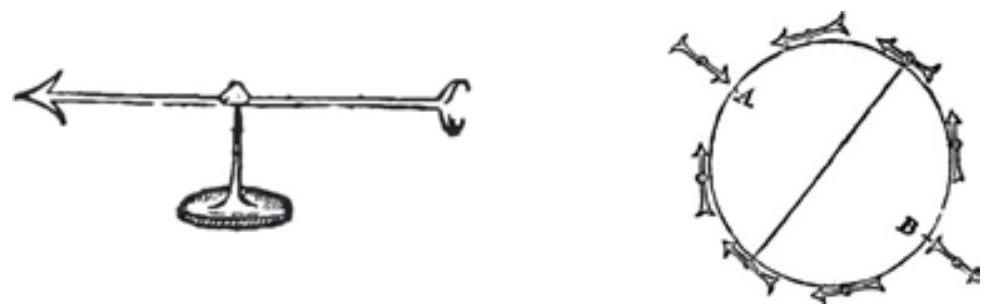

Figure 1: Illustration from William Gilbert's De Magnete of an instrument, an arrow-shaped versorium, and a diagram illustrating magnetic influences around a magnetised earthlike sphere (Gilbert 1600, 49 and 135). 
Arrow images crop up widely in scientific literature. In 1600 when bows and arrows were dying out as part of England's armoury, a treatise on magnetism published by the Englishman William Gilbert included diagrams showing a number of arrow-shaped "versoriums". The arrow sign on Gilbert's magnetised versoriums indicated the direction of magnetic influences. One of his illustrations, reproduced on the left of figure 1, was accompanied by a description of how to make a versorium implying the picture was an image of a constructed physical instrument that carried an arrow sign. However, many of Gilbert's illustrations like the one on right of figure 1 showed versoriums schematically around magnetised bodies. These diagrams were not images of particular situations or of collections of instruments, but summaries of several possible experiments and therefore a part of a theory. For example, the diagram on the right of figure 1 encourages speculation on how versoriums would be affected in as yet unexplored locations around the terrella. Thus arrow signs are found in different contexts some, like the physical versorium, to guide an immediate determination of a state of affairs and others providing an element in the lexicons of theories that guide deliberations on what could happen.

There have been studies of the use of arrows employed in diagrams in several scientific disciplines. Schott, whose interests lay in cerebral functioning, saw the arrow in diagrams of the brain's activity as "a remarkable symbolic device" $(2000,1789)$ and, he observed, "the use $[\ldots]$ of this elegant symbol" is "often contentious" (Schott 2000, 1798) and, he acknowledged, arrows are deployed in diagrams without explanation or indication of their purpose (Schott 2000, 1796). Alvarez presented a host of uses of images of arrows in chemistry, from alchemy to the description of catalytic cycles and photochemical processes. He emphasised the radical differences in uses of the symbol, for example the differences in use of similar shaped arrows which are "horizontal, uppointing, or down-pointing [...] within a chemical equation" (Alvarez 2011, 599), and according to Heiser and Tversky $(2006,582)$, in diagrams of mechanical systems, arrows "express many relations, among them pointing or connecting, sequence, change over time, path, or manner of movement or forces" as well as relationships between presumed causes and effects.

\section{The Honourable Arrow}

Arrows have been a part of many cultures. Historical references might be taken from a number of sources from different parts of the world. In this paper my primary focus is on the literature of England and what were once its North American colonies.

The obsolescence of the arrow as an English weapon of war in the 1590s triggered a controversy. Supporters of firearms, such as Williams (1590, 41-43), set out to "proove Bow men the worst shot"; they reckoned weapons such as the arquebus were more effective than bows and arrows, though such claims have been challenged, for example, by Benjamin Franklin $(1776,170)$ who believed, "bows and arrows [...] were good weapons, not wisely laid aside". The advocates of archery adopted a moral stance; they argued archery was "wholesome for the health of the bodie" and exercised the mind "honorably" since in archery practice "a man always desireth to bee best" (R.S. 1596, B2). Archery, it was supposed, prevented "drunkennes and other evills" (Smythe 1590, A2) and was "a medicine to purge the whole land of all pestilent gaming" (R.S. 1596, at end of Part II). However by 1598 in London "the auncient dayly exercises in the long bow [... were] almost cleane left of and forsaken" (Stow 1598, 77) and it was these persistent lax attitudes towards archery practice that made it impossible to assemble an effective body of bowmen (Esper 1965). By 1674 archery was "quite laid aside by English Men for fighting", and although archery was "used by some for pastime" (Cotton 1674, 203), in his book of games Cotton gave only a brief treatment because, he explained, "it is so little used now adays" (Cotton 1674, 204).

Nostalgia for the Gothic and the medieval, towards the end of the eighteenth century, led to the resurgence of recreational archery by the English upper classes (Johnes 2004). Whittaker (1880, 60) reported on the "sudden and remarkable revival" of archery in England and attributed the development of the sport in the United States to Maurice Thompson $(1877,287)$ who eulogized bows and arrows by presenting them as "natural" weapons which were "to the mind and body what music and poetry are to the soul"; earlier Hastings $(1831,118)$, a North American, displayed similar sentiments, describing archery as eminent amongst the "Fine or Polite Arts" and capable of increasing "social happiness".

Hansard (1841, iv) not only presented archery as "a wholesome and graceful exercise" but he also regarded its history as "a brief chronicle of England's martial daring, for at least six centuries" and "a source of a thousand romantic speculations". Henry VIII (1528), for example, proclaimed that the bow and arrow were instrumental in "many notable exploites and actes of warre" and Ascham $(1545,41)$ insisted, "The feare onely of Englysh Archers hathe done more wonderfull thinges than ever I redde in anye historye greke or latin". Queen Elizabeth I's Court made the proud claim 
that through archery "our nacion in tymes past hath gotten [...] great honour" (Elizabeth I 1591, 175), and late sixteenth century English supporters of archery reckoned that through archery their ancestors had made the nation famous with their "many miraculous victories" (Smythe 1590, A2).

Specific battles have often been singled out. Holinshed $(1577,1199)$ wrote an influential account of the Battle of Agincourt and remarked on "the high valiancie of the English people, with the ayde of theyr Bowes". The mythology persisted. Cecil Beaton $(1942,18)$, for instance, told of wartime pilots who practised recreational archery and described them as "champions of the most modern of all long-range weapons [who] are adepts at the bow and arrow, through which the English archers won the battle of Agincourt". More recently, A. A. Gill $(2012,51)$ wrote, "English archers have attained a mythic status down the ages" which he attributed in part to victory at Agincourt and another newspaper article opened with the assertion, "AGINCOURT. After nearly six centuries, it's still a name that rings triumphantly in the English ear" (Hart 2009).

The arrow image thus records an obsolete weapon with a mythic, noble past kept in the English public consciousness by historical accounts, romanticized revivals and honourable legends such as the stories of Robin Hood already well known in the 14th century (Brockman 1983). The image of the arrow has therefore been transformed from that of a vicious debilitating weapon by an association with a gentrified sport and a glorified past to become an accepted and familiar component of public signs.

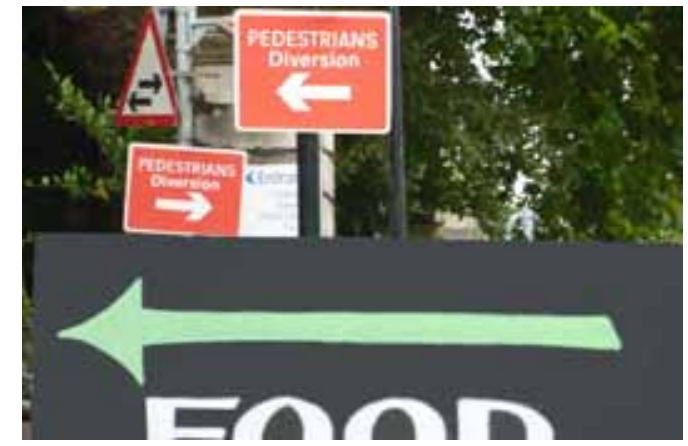

Figure 2: An urban scene in London in 2011.

Nowadays arrow images appear on signs in places such as airports (Fuller 2002) and everyday urban settings as figure 2 shows. And, it seems, they have a variety of uses and address a variety of audiences. What is immediately apparent about the arrows in figure 2 is that they lose their utility if they are moved. Location and orientation are constituents of such arrow signs.

\section{Shape}

There is no single shape or outline that characterises an arrow. The collection of images from present-day signs shown in figure 3 illustrates a variety of shapes that would undoubtedly be called arrows. An element of the variety arises from the range of materials that make up these signs such as painted wood, chiselled stone, brass mounted on marble or enamelled or cast metal. Some of the variety is a result of the different tools available to the sign writers together with differences in their skills and available resources. Part of the diversity is also due to different sign writers' interpretations of what an arrow should look like and therefore dependent on the exposure of the sign writers to other images of arrows either on signs or in historical illustrations, accounts or legends.

Illustrations in early books on archery show that arrows themselves came in a variety of shapes (Moseley 1792, Plates 2 and 3). Roger Ascham $(1545,19)$ acknowledged the "Fashion of heades is divers" and, referring to arrows in antiquity, identified one sort with "two poyntes or barbes, lookyng backewarde", which he called the "Englishe a brode arrowe head or a swalowe tayle", and another having "having ii. poyntes stretchyng forwarde", which he called "forkehead" and is a shape unlikely to be a prototype for a present-day arrow sign. Ascham also described the merits of different arrowheads for "prycke" shooting - a kind of target practice. He explained, "as concernyng heades for pryckyng, $[\ldots]$ there be dyverse kyndes, some be blonte heades, some sharpe, some bothe blonte and sharpe" (Ascham 1545, 21). Arrows for shooting practice in England, Walter Moseley observed, "as they are not designed to inflict death, are not very sharply pointed" (1792, $134)$ and he noted, "there were great variety of Arrow-heads used in war" (1792, 132). He described arrows as "sometimes barbed, sometimes plain and long [...] often flat, and nearly resembling the leaves of some vegetables" $(1792,131)$. 


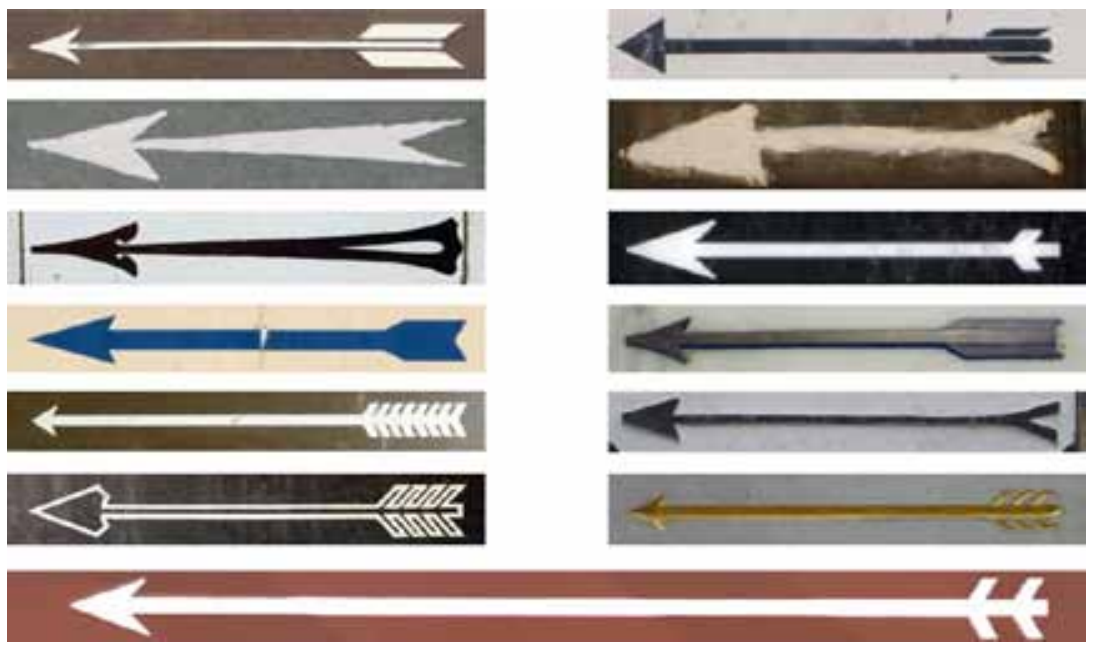

Figure 3: A collection of arrow images from signs photographed in publicly accessible places in England and Belgium.

There was, therefore, no single specific shape for an arrow consequently arrow images on signs belong to a family of shapes rather than being reproductions of a well-specified image. In spite of the variety, Moseley's brief survey opened by stating, "[the] figure of the Arrow has undergone less variation than that of the Bow" and concluded, "Arrow-heads [...] found in countries the most remote from each other, are all nearly alike in figure" $(1792,124)$. The similarity in shape of arrowheads from many cultures and eras suggests that the images of arrows will be universally recognised.

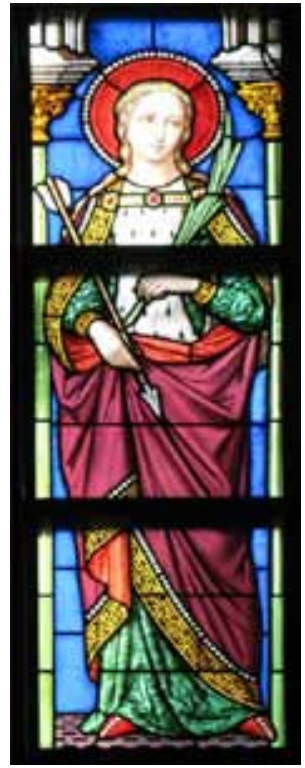

Figure 4: St Ursula portrayed in stained glass in Antwerp Cathedral holding a palm leaf and an arrow as emblems of her martyrdom.

Images of arrows can be emblematic; for example figure 4 is an allegoric picture symbolizing the martyrdom of St Ursula who rejected the advances of a prince holding her captive, whereupon "he shote at her an arow and perced her thorugh the body" (de Voragine 1483, 337).

Emblematic images of arrows and arrowheads also appear on heraldic shields and have a limited variety of shapes. According to Fox-Davies $(1909,283)$, in heraldry "arrows are very frequently found [and] Arrow-Heads and Pheons are of common usage". Figure 5 shows three commonly pictured heraldic forms. Pheons have "engrailed" inner edge whereas arrow heads "without this peculiarity they are termed "broad arrows"' (Fox-Davies 1909, 283). Guillim $(1679,247)$ regarded the pheon as "the head of an Instrument of the Missile sort". The head was attached to "a long and 
light staff" with "a thong fastened to the middest thereof". He explained, "it pierceth speedily, and maketh a large wound, by reason of the wide-spreading barbs thereof."

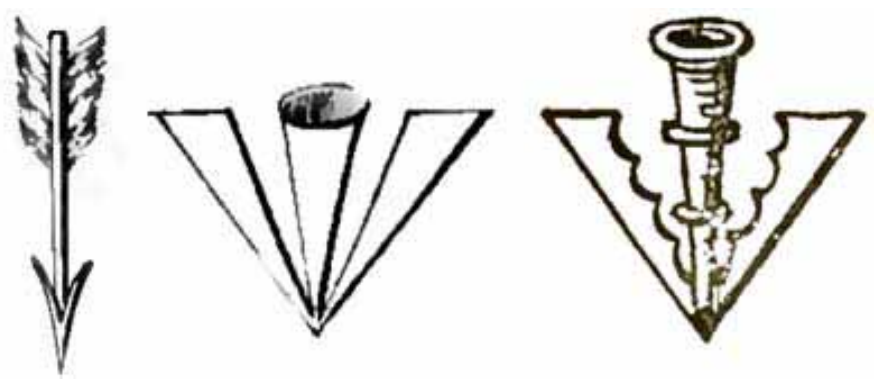

Figure 5: Images of arrows used as heraldic charges. The leftmost image is a barbed arrow second from the left is a broad arrowhead (Berry c1830) and the rightmost head is a pheon (Renton 1889).

The broad arrowhead shape found its way into the design of many present day arrow signs, commonly modelled on the form described in Guillim's account of the pheon with a shaft and without fletchings. Figure 6 shows several such broad headed arrow signs which are clearly different from the shapes of arrows in figure 3.
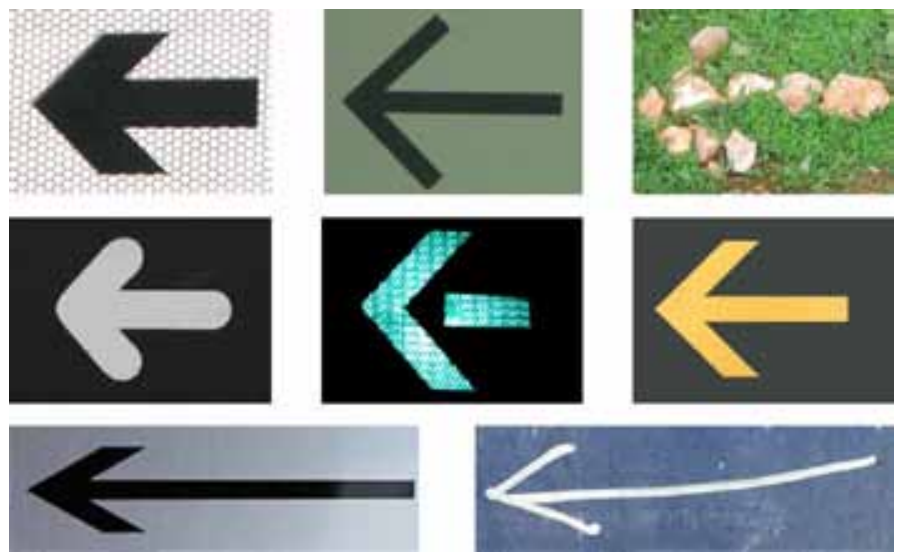

Figure 6: Arrow signs modelled on the broad arrow head photographed in public places in the UK and Canada

Arrows intended for war such as the barbed arrow to the left of figure 5 required different characteristics to those used in sport. For instance, Ford (1856) recommended a straight sided arrowhead for recreational archery pictured in figure 7 . This shape of arrowhead has an outline that has influenced signs such as that shown in the image in figure 8.

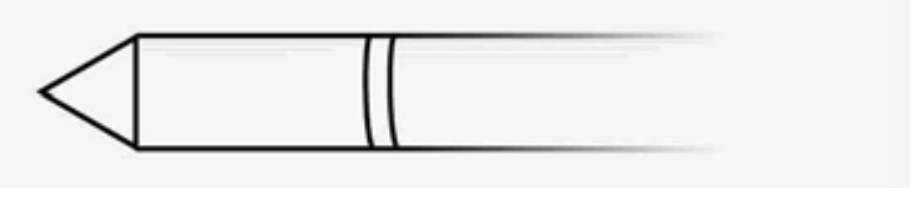

Figure 7: A parallel sided arrowhead, or pile, for recreational archery attached to a shaft (derived from Ford 1856 Plate 5)

Arrow signs are thus constructed from a variety of materials and shapes that draw on a variety of arrow artefacts. In addition the creator or designer of an arrow sign can deploy artistic styles, variations in colour and textures that all add to the range of possibilities, and provide opportunities to express more than a single basic function in a sign. At best, arrow signs as a category offer a family resemblance in form and function (Rosch and Mervis 1975; Wittgenstein 1992, §67). 


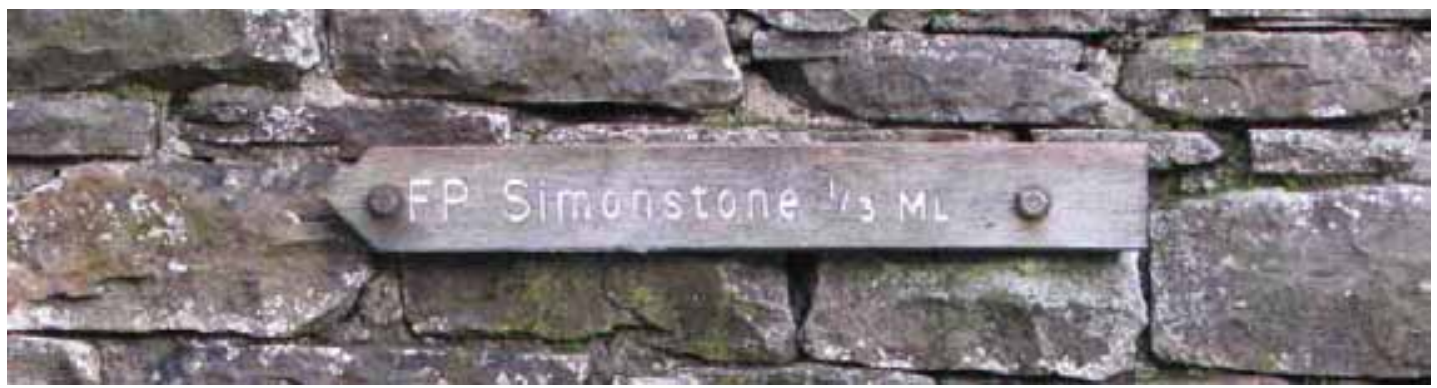

Figure 8: An arrow sign of similar shape to the parallel sided arrowhead with its shaft.

\section{The Broad Arrow}

Arrow images on signs can have many different forms, and each form could have a variety of uses. English broad arrow signs, for instance, constitute a family of signs which exploit a particular arrow image. However on its own a broad arrow sign does not signal a particular use; there are a number of radically different practices that incorporate broad arrow images with each practice characterized by specific relationships amongst particular groups of actors.

\subsection{Uses of the Broad Arrow}

The narrative in a popular novel, entitled The King's Own, associated the broad arrow with the book's title and explained: "The broad-headed arrow was a mark assumed at the time of the Edwards [...] as distinguishing the property of the King ; and this mark has been continued down to the present day. Every article supplied to his Majesty's service from the arsenals, and dockyards is thickly studded with this mark ; and to be found in possession of any property so marked is a capital offence, as it designates that property to be the King's own." (Maryatt 1830, 22)

A great deal of recorded evidence supports this fictional account. For instance, figure 9 shows part of the carriage of a canon, one of several, overlooking the St Lawrence River in Quebec City. The broad arrow mark is readily apparent and the year of manufacture, 1807, is also inscribed. The canon barrel carries George III's monogram.

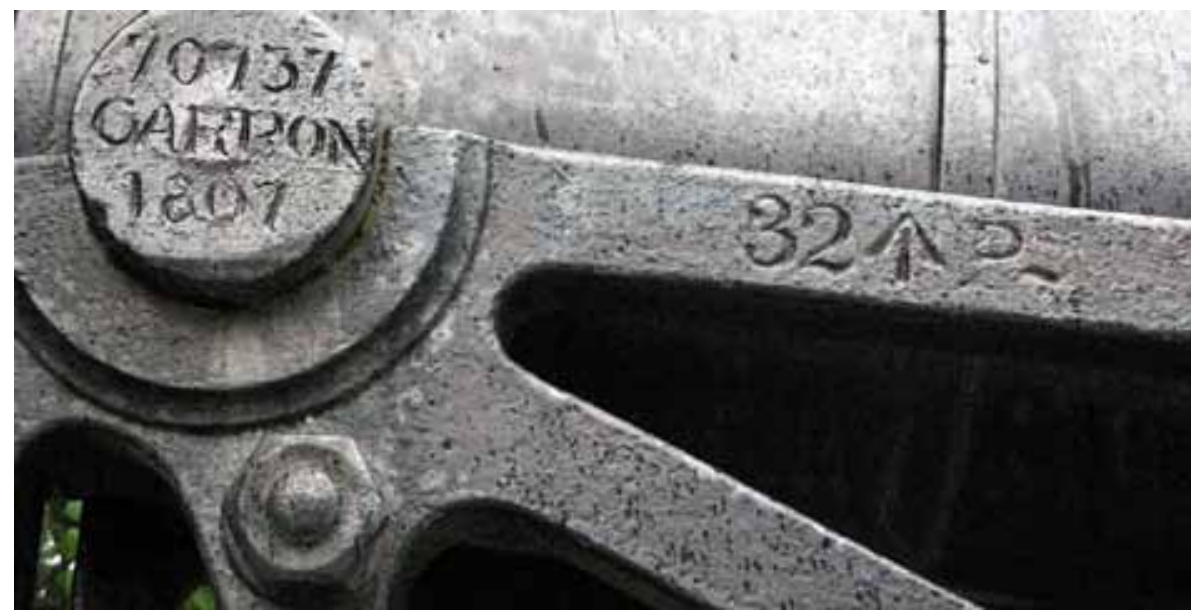

Figure 9: A broad arrow mark to the right of the picture on a gun carriage stationed in Quebec City.

An account from an earlier age describes a fraud perpetrated around Christmas in 1386, when Thomas Stokes masqueraded as a "taker of ale" for the Royal household. He visited a number of brewers' houses and fraudulently marked "several barrels full of ale with a mark, called "arewehede," saying that those barrels were for the household of our Lord the King" (Riley 1868, 490). Over a century afterwards, on the twenty-ninth of November 1554, a correspondent in Seville reported agents of the English Queen Mary had transferred a large sum of money in fifty cases "each marked with the broad arrow" (Gresham 1554, 141). Subsequently, in a complaint about a shoddy brass castings, Burrowes and Taylor $(1670,350)$ lamented, the castings were "neither marked with the broad arrow nor any other mark, as is usual with the King's goods". More recently in a glossary 
under the heading "BROAD ARROW" Stone $(1934,150)$ confirmed, the arrow was "still used to designate the property of the British navy", and in a 1987 revision of a 1984 standard, the British Ministry of Defence issued guidance for marking military materials with marks described as the “'BROAD ARROW' OR 'PHEON"' similar in shape to those in figure 10. (MOD 1984, 27).
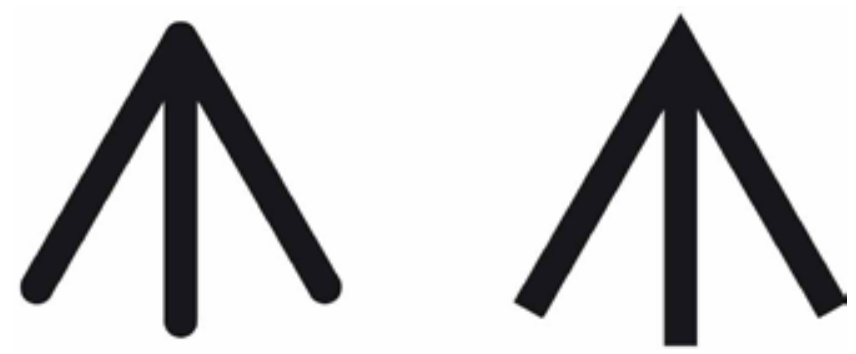

Figure 10: Broad arrows drawn to meet the proportions defined by the British Ministry of Defence Standard 05-34/2 (MoD 1984 27).

For archaeologists the broad arrow is a potential symbol of past practices and relationships. One archaeological investigation of a sunken ship, for example, found "numerous loose copper artefacts [... and f]ragments of detached copper sheets [...] marked with the English broad-arrow" (Tomalin, Simpson, and Bingeman 2000, 7-8). The archaeologists concluded that clearly the ship was an English Navy vessel and that it would have been more difficult to determine the ship's nationality without the evidence of the arrow markings (Tomalin, Simpson, and Bingeman 2000, 9).

As well as the broad arrow marking goods bought for the King, Pepys $(1926,307)$ mentioned marks on goods that belonged to the King which had been recovered and goods "forfeited to him as at the Custom House". Similarly, in the fifteenth century, according to Welch's (1902, ix) history of the London Company of Pewterers, "All bad ware or metal was marked with the Broad Arrowhead" and, Welch added, "it was doubt-less the fate of all vessels marked with the broad arrow to be forfeited and melted down without delay" (Welch 1902, 47). Evidence comes from the Company's records which, in the inventory for 1489-1490, mentioned an iron punch with "abrode arowe hede grauyn therin" (Welch 1902, 69) and an entry made in the year 1564-65 refers to the "mending the Brode Arowhede" (Welch 1902, 249). A delivery note issued during 1474-1475 revealed the purpose of the punch by describing it as having a "brode arowe hede fore the forfet marke" (Welch 1902, 47).

Records also show that at one time English sailors detaining vessels on behalf of the monarch marked a ship's mast to signal the arrest. For instance, on April 171633 a gunner and a Mr. Smith arrested two merchant ships. The crew "suffered Mr. Smith to mark the broad arrow upon the mainmast". Alas the crew refused to surrender the apprehended ships' sails and "[t]he next day the two East India ships slipped their cables and anchors and made sail" (Tourney 1633, 22), thereby thwarting the arrest. A similar event occurred in 1693 when ships were commandeered for military service; an official account referred to the broad arrow as the "Broad R" and noted that the Victualling Commissioners "finding a want of shipping to supply the Fleet with beer [...] took up such ships in the river as were ready and fit for that service; but after having set the Broad R upon them they have gone away and declined the service" (Guy 1693, 219). In another case, in 1696, an officer of the Excise Commissioners "set the broad R upon the copper" of a brewing vat when the impecunious brewer was unable to pay a demand for excise duty (Treasury 1696, 222).

The broad arrow also found use in reserving timber in forests. For instance, in 1667 an Act of Parliament demanded that two or more Justices should assess the maturity of trees in the Forest of Dean and if they reckoned a tree was fit for felling they should mark it "with a broad Arrow and Crown" (19 \& 20 Cha. 2 c. $8^{1}$ ), however in 1772 in Sherwood Forest where similar rules applied it was reported that three defiant verderers "would not regard" the broad arrow marking the trees "for his Majesty's use" (Wither 1722, 143).

In another context, Augustus Such $(1841,11)$ described the uniforms prisoners wore in Millbank prison that were conspicuously "stamped on the arms, back, and legs with B. O. and the broad arrow $[\ldots]$ in white paint". He was puzzled because he believed B. O. and the broad arrow were

\footnotetext{
${ }^{1}$ Identifiers of Acts of Parliament in Britain before 1963 are formed from the regnal year or years of the parliamentary session in which the Act was passed and a chapter number. A regnal year is the number of years into a monarch's reign (starting with year 1) followed by an abbreviation of the regal name of the monarch, such as Cha. 2 for Charles II. The chapter number, often preceded by "c." is the sequential number of the Act within the parliamentary session.
} 
marks for Board of Ordnance property. Later, an unknown convict also wrote about Millbank prisoners' uniforms, which were then covered with "hideous black impressions of the Broad Arrow $\uparrow$, the 'crow's foot"' (Anon. 1878, 68). After transferring to Dartmoor prison the same felon worked on new prison garments and "marked them with the broad arrow, stamping them all over in regular allotted places [...] with black paint, and [...] with red" (Anon. 1878, 307). Another internee, John Mitchel $(1854,57)$ described the occupants of a prison hulk he encountered during his enforced odyssey as "men in white linen blouses and straw hats - and on the back of every man's blouse [...] the queen's broad arrow". In 1846 an issue of the Illustrated London News depicted prisoners attending a chapel aboard a prison hulk with arrows printed on their shirts (Anon. 1846) and over fifty years later a photograph, in another edition of the same periodical, depicted prisoners from Portland Prison in church with large broad arrows marked on their clothes (Anon. 1910).

Cartoonists who wanted to portray convicts or wrong-doers adopted the broad arrow image stamped on prisoner's clothing. For instance, the cartoon in figure 11 caricatured a convicted contractor who supplied shoddy goods and unpalatable rations to the army and who is complaining about prison food. Similarly in a written satire the writer alluding to the criminal practices of some builders wrote about them as "Certain gentlemen who have since been awarded the decoration of the Broad Arrow" (Anon. 1895).

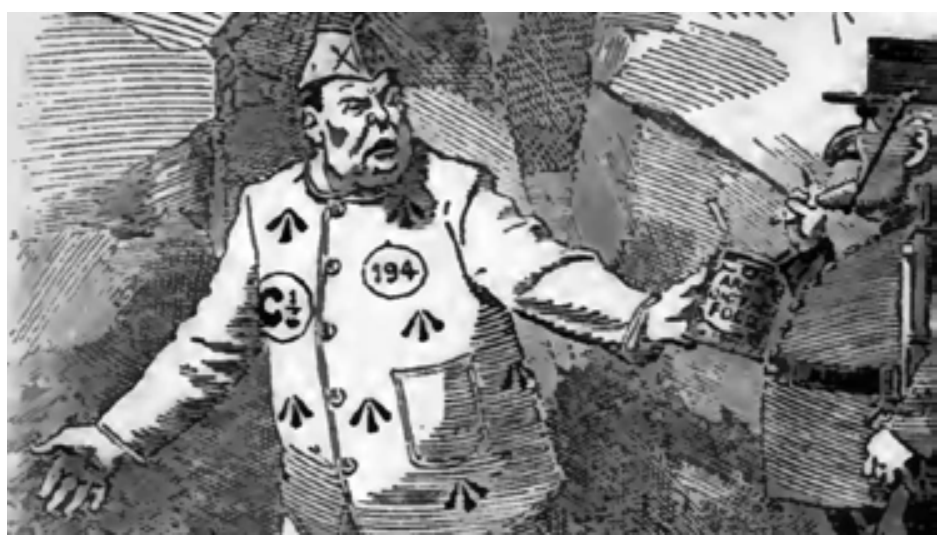

Figure 11: An extract from a cartoon identifying a convict wearing a uniform covered in broad arrows (Sambourne 1910).

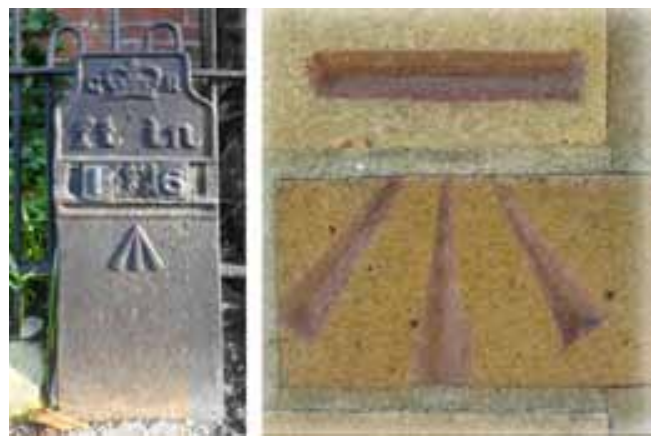

Figure 12: On the left a metal benchmark in the village of Beaulieu. On the right a benchmark cut into brick on the side of a house in Buckingham.

In a radically different field, the Ordnance Survey, a government agency, was charged with mapping the United Kingdom. Around 1790 the agency grew from the surveying activities of the Board of Ordnance (Irwin 1977) and set about creating a network of triangulation lines and bench marks that provided surveyors with reference points of known elevation. Indexes recorded the bench marks' locations and heights (or "levels") and on the ground the bench marks incorporated a familiar symbol: "The three volumes containing the levelling, [had] indexes showing the lines which have been levelled [surveyed] throughout the kingdom, and along which marks $\mathbb{T}_{\text {(a broad arrow }}$ with a horizontal line, to mark the exact point to which the levels are given) have been cut upon permanent objects, such as churches, bridges, \&c., for reference" (Murchison 1860, 180) 
Technological change in map making has rendered bench marks redundant but they can still be found on buildings and boundary posts. Figure 12 gives two examples. Both benchmarks show clearly the Ordnance Survey's signature of the broad arrow with a horizontal line above the arrow defining the height relative to a national reference. The broad arrow identified them as authorised bench marks with entries in the national index.

Clearly, the broad arrow mark has had a variety of uses and could identify royal goods, secern fine trees, mark an arrest, signal the commandeering of a ship, denote a forfeit, identify the authority behind a benchmark or differentiate a convict in person or as a caricature. The shape of an arrow image alone, therefore, does not uniquely establish how a percipient is expected to respond to a sign.

\subsection{Origins}

Over many years correspondents to Notes and Queries posed the question "What is the origin of the arrow head as a government mark?" (Anon 1851). One thesis, which the claimant admitted lacked supporting evidence, was that an "Arrow shot would formerly give the limit of dominion to kings' rule. Hence possibly the mark of the broad arrow. Everything so marked would show that it lay within royal authority and protective rights." (Ward 1884). As an alternative, the respondent P.C.S.S. (1851, 371-372) presumed the "broad arrow" on government stores represented the "Pheon" adopted from the arms of Henry Sydney who, around 1700, was Master-General of the Ordnance. Bradridge $(1925,283)$ repeated that claim and added that Henry Sidney on "finding that Government stores were being stolen [...] caused the pheon to be stamped on the stores".

Although it was commonly referred to as a broad arrow, the simple shape of the "king's mark" has been speculatively traced to other named forms and artefacts. One writer suggested the mark might be "traced back to the mysteries of Mithras" but admitted that this was "merely thrown out as a conjecture" (J. M. 1852, 116). A different suggestion was that the broad arrow had a "Celtic origin; and that the so-called arrow may be [...] the broad [letter] a of the Druids" (A.C.M. 1851). This proposal got support from a later contributor who maintained the broad arrow was "derived from an ancient Cymric sign called the three rods or rays of divine light, which signified the radiating eye of divine intelligence shed upon the Druidic circle" (A.F. 1925, 153).

The English Admiralty employed the broad arrow and this puzzled Samuel Pepys $(1926,311)$ who wrote, "had our Princes valued [...] their sea doings and sea power, they would have taken their public brand, especially that which was to serve them in sea matters [...], from some thing really relating to that element rather than to an arrow-head". He felt the symbol could be a roughly drawn anchor but accepted the wording of the English laws which identified it as a broad arrow.

Harris (1914) suspected the broad arrow mark was modelled on an image of a gallows in the form of a tripod. He cited Robert Ward as the source of this proposition. Ward offered advice to soldiers and wrote, for instance, about preventing the theft of tools such as "Iron-shovels, Mattockes, Pick-axes, Axes, Hatchets, Hookes, Plants, Boordes, Hurdles, Mandes, Baskets, Wheelebarrows" and so on which, he considered, "ought to be marked with the Gallowes" and, Ward added, "hee that steales them dyes without mercy" (Ward 1639, 108). Later in his book he advised, "Amunition, with Axes, Mattockes, Spades, and the like to build their Hutts withall; these instruments are to have the marke of the Gallowse set on them, in token of death to them that steale them" (Ward 1639, 200).

Whether or not the gallows or the anchor are alternative names for the English monarch's broad arrow or whether or not it is modelled on an arrowhead is not entirely clear, but Ward made the crucial point that it is useful to have a distinguished mark to prove that someone has appropriated military goods. A symbol other than an image of an arrowhead could perform the same functions.

The origins of some uses of the broad arrow can be traced easily. Archaeologists and cartoonists, for example, appropriated the symbol that had a distinctive use in practices other than their own and exploited it in their stories of the past or their contemporary satires. It is not clear how the broad arrow came to be on prisoner's clothing though Such's observation that in Millbank uniforms included the initials B.O. (Such 1841) suggests a link with the Board of Ordnance, which was responsible for holding military stores. Fairbrother $(1914,482)$ approached the Prison Commissioners who replied on the 2 March 1913, writing they were "unable to supply with any precise particulars as to when the broad arrow was first used to brand prison clothing" but they did indicate the arrow had been in use "in Convict Prisons and Hulks for more than 80 years, and was also used in Australia". In contrast, the link between the Ordnance Survey and the surveying activities of the Board of Ordnance provides a clear explanation for the adoption of the broad arrow on Ordnance Survey bench marks. 
Speculations on the form, origins or name of the broad arrow symbol did not affect its various uses but those speculations do emphasise a degree of arbitrariness in the adoption of an arrow image as a symbol. Superficially the origins are unimportant. Functionally all that was required to support each use of the broad arrow was a distinctive sign and provided people were educated in the uses of whatever symbol was chosen the sign would fulfil its function. However it is clear in the protracted correspondence in Notes and Queries that people yearn for a story to tell and wish to use symbols that have a history, and for some uses, in for example archaeology or satire, a history is essential.

\subsection{Duration and Support}

Since the image of the broad arrow does not bear an obvious connection with its various uses, on occasions authorities advised potential sign makers and readers of the practices surrounding the arrow's application. For example, the British Ministry of Defence standard implied that marking goods with a broad arrow provided a "psychological deterrent to theft" and therefore was to be "used on items of an attractive nature if it seems likely that the marks would deter theft" (MoD 1984, 26). Similar sentiments were revealed in an early series of English decrees, bills and laws. In November 1661 during Charles II reign, a proclamation about the discovery and punishment of the embezzlement of Navy stores required certain of the King's goods to be marked with the broad arrow "by Stamp, Brand, or other Way" (Charles II 1661, 2). Faced with continuing pilfering, William and Mary (1693) issued a proclamation "For the Preventing of the Stealth and Imbezilment of Their Majesties Stores of War" and announced goods were to be marked with "the Broad Arrow, by Stamp, Brand or otherwise". In 1697 an Act was passed which required "Warlike and Naval or ordnance Stores" to be marked with the broad arrow (9 Will 3. c.41).

A further series of laws reiterated the obligation to mark Royal goods with a broad arrow. Under George I in 1722 an Act included clauses on "the Preservation of Naval Stores, and Stores of War" (9 Geo. 1 c.8) and in 1800, during George III's reign, a similar Act was passed which referred to "Naval, Ordnance, and Victualling Stores" (39 \& 40 Geo. 3 c.89). An Act of 1815 extended the marking "to all other public Stores" (55 Geo. 3 c.127) and Queen Victoria's parliament introduced a Public Stores Act in 1875 that, with few exceptions, required the State's stores to be marked with a crown, the royal arms or a broad arrow (38 \& 39 Vict. c.25).

In the twentieth century, a proposed Government Marks Bill attached to a note from Winston Churchill, Secretary of State for War included a schedule reaffirming the broad arrow as a valid mark of state property (Churchill 1920). Thus the practice of marking goods with a broad arrow was established by English law by a succession of attempts to curb theft. The mark did not simply declare something to be the King's property in the absence of a crime but ensured there was evidence indelibly linked to an object when a theft was alleged. The explicit connection with the Crown made it clear that there were likely to be agents seeking thieves and if a theft was discovered then punishment would ensue. Marking the goods with a well-known mark, it was hoped, would then discourage theft, though current views on deterrence and crime challenge the effectiveness of such measures (Paternoster 2010; Wikström, Tseloni, and Karlis 2011)

\subsection{A System}

If the unauthorised trading of military and latterly public goods, was to be prevented, the broad arrow had to be placed on goods by manufacturers who required suitable tools or manufacturing equipment. For instance, in 1844 the King of Saxony during a visit to the naval works in Portsmouth witnessed the machinery that imprinted marks on copper sheathing. He "observed how the metal is melted, how it is then flattened out by means of rollers, and how the last roller impresses on it in every part the mark of all the property of the royal navy - the broad arrow: so that one can see upon every little bit of copper that it has been manufactured in a royal arsenal" (Carus 1846, 52).

Inevitably, fraudsters found it profitable to forge the king's mark on sub-standard goods, which could then be sold to unwitting crown authorities, and some racketeers illegally removed the marks to make stolen goods marketable. For example, in the dockyards in and around London dishonest metal traders took on men who were "employed in knocking the Broad Arrow out of copper bolts, nails, bar iron, and other articles, on which it is impressed, so as to elude detection" (Colquhoun 1797, 83). These subversive activities demanded policing actions and legal strictures to maintain the integrity of the system of ownership. Consequently, the 1875 Stores Act set penalties for fraudulently applying the mark, erasing the mark or having unauthorised possession of marked goods, and the draft bill of 1920 proposed outlawing the unauthorised application of government 
marks and criminalising the possession of "dies or other appliances by which the marks in question could be produced" (Churchill 1920).

A mark such as the broad arrow on a canon was, therefore, an instrumental part of an extensive socio-technological system embracing a variety of practices such as law making, manufacturing, machine fabrication and the exercise of techniques for imposing authority such as the detection of fraud and theft and effective punishment regimes. Nefarious schemes for evading authority were also enmeshed in the same system by an interest in the appropriation, application or removal of the broad arrow. Accordingly broad arrows marking property bound together radically different ways of life and connected their practitioners including thieves, those tempted to steal, manufacturers, law makers and enforcers. However the broad arrows identifying Ordnance Survey benchmarks engaged different people, different skills, different equipment and established different relationships from those engaged in upholding a monarch's property rights. Thus the broad arrow was a component in several loosely connected systems offering different social functions and embracing different sets of practices. The particular shape of an arrow symbol was therefore not associated with a particular institution, system, group of participants or set of objects, and radically different uses could arise in different geographical places or with different groups of people; for instance, Richardson in describing his travels in the Sahara wrote,"the camels have all public and private marks, the former for their country, and the latter for their owner, and, strange enough, the public mark of the Ghadames camels is the English broad R. So when a camel is stolen, a man claims his camel by his mark" (Richardson 1848, 420).

However the Ghadames people were not a part of the English system and their use of the familiar symbol for an apparently similar purpose to the King's mark was coincidental and defined by their own practices and cultural developments.

Uses of the broad arrow demonstrated that it is the activities of the participants within a system that established particular functions of a sign and a particular form of sign can be part of several separate socio-technological systems.

\subsection{Emotional Impact}

The deterrent effect of the broad arrow on state property relied on the fear of being caught with marked goods. Signs can, therefore, stir emotions. It has also been noted that "the prison uniform with its broad arrows [was] intentionally demeaning and unsightly" (Edwards and Hurley 1981). Convicts were humiliated by wearing the "grotesque garb, dotted all over with broad arrows" (Balfour 1907) and in 1922 the Prison Commissioners hoped the new and simple clothing without a broad arrow would "give a better chance to self-respect" when they announced "Broad arrows [... were] being removed from the outside of prison clothing" (Prison Commission 1922).

The repercussions of using the broad arrow in the forests of the British North American colonies were far reaching for the colonialists for whom the broad arrow became a sign that aroused anger and resentment. In 1629 a Charter was issued to govern the affairs of the Massachusetts Bay colony; it licensed fishing and permitted the settlers to "cut down, and take ... Trees and other Materials" (Charles II 1629, 25). William and Mary (1691) issued a second Charter which added a new provision for "the better provideing and furnishing of Masts for Our Royall Navy" that removed earlier rights and restricted the cutting of large trees. In pursuance of this new Charter, English government officials marked large standing trees to indicate they were the Monarch's property with "the "Broad Arrow" - the old sign of naval property, shaped like a crow's track and made with three blows of a marking hatchet" (Albion 1926, 241).

The new Charter regulations proved ineffective and the Surveyor General complained, "everyone [was] going into the woods in defiance and cut[ting] what they please" (Bridger 1710, 19). An Act of 1710 put into law the delegation of authority to the Surveyor General or his officers to mark "with the broad arrow all such trees as now are, or hereafter shall be fit and proper to be taken for the use of her Majesty's royal navy" (9 Ann. c.22). This Act also recognized some settlers had appropriated the broad arrow symbol and whatever authority it carried; for example, the Surveyor General alleged, "some ill men have this last winter gone into the woods and marked all trees before them, those trees fitt and unfitt for masts, with the Broad Arrow [...] and when theire neighbours come into the woods to get loggs for boards etc., they seeing all the trees marked immediatly returned, thinking that I had ordred the marking" (Bridger 1708, 169).

The Act therefore outlawed the unauthorized marking of "white or other sort of pine trees, with the broad arrow". However, it seems "The yearly wast and destruction made in H.M. woods [was] continuing" (Bridger 1711, 524). The woods were to be surveyed and the larger trees marked but Bridger complained, "to put these Instructions in practice gave [him] very much trouble; and the people dissatisfaction" $(1718 a, 307)$ whereas he would claim the authority of the Crown, local peo- 
ple would refer to the "privileges of the Charter" consequently "the Charter is allways pleaded and the reservation for H.M. Navy is null'd" $(1718 a, 308)$. Bridger $(1711,524)$ earlier explained, "H.M. can never hope of any justice here, where judge and jury are offenders". He observed therefore "'tis in dispute whether H.M. has any woods in this governmt or no" (Bridger 1718b, 311).

Also some cunning schemes exploited the letter of the law. For example, the regulations allowed the felling of trees within the townships but Armstrong $(1720,231)$ reported "the people $[\ldots]$ have taken in thousands of acres wherein the best timber grows, and form the same into their townships, tho" the thousandth part thereof is not under any immediate improvement etc". There was a straightforward disregard of the legal prohibitions (Armstrong 1722), some evidence the government agents were bribed and criticism of the drafting of the legislation (Armstrong 1721).

A new law in 1721 imposed more stringent penalties on those cutting trees and those transporting them without permission. It also allowed conviction in an Admiralty Court on receipt of "Information, upon the Oath of one or more credible Witness or Witnesses" with one half of any proceeds going to the informer (8 Geo. $1 \mathrm{c.12}$ )।. It seems this added to the confusion between the "Charter which obliges us to try it at common law, and in the act [...] wch. only prohibits cutting trees without townships wch. we are to try in the Court of Admiralty" (Dunbar 1729, 472).

Complaints from the officials continued, in some instances they were confronted by violence and the impossibility of imposing the law when the "owners of mills were [also] magistrates and officers" (Dunbar 1734, 92). The settlers too were aggrieved, partly because in the trials in the vice admiralty courts could be carried out without a jury (Surrency 1967). The Surveyor General felt the naval jurisdiction was ineffective and declared, "As to the woods, my deputys and I meet with so much discouragement from the Judge of Vice-Admty. as encourages the loggers, who treat us with scorn" (Dunbar 1732, 200).

In New England, the broad arrow came to signify oppressive policies and provoked wide-spread discontent, which was compounded by "the added oppressions of the last decade before the Revolution" (Carlton 1939, 11), and as a consequence of the impotence of the King's agents in the colonies the "importance of [...] the king's "broad arrow" was probably more symbolic than real" (Tolles 1954, 6). That is the broad arrow failed as a deterrent and became a provocative emblem of an unappealing government.

In addition to limiting rights over timber, in 1765 at a time of economic hardship, the British government passed the Stamp Act, which infamously imposed additional taxes on the American colonialists. An American newspaper recorded the feelings of the colonialists and announced, "it manifestly appears to be the unanimous sentiment of all his Majesty's free and loyal subjects throughout his extensive dominions in America, that the STAMP ACT is not legally binding on them" (Anon. 1765). The Act was repealed a year later and the politicians of the time were lampooned in a number of cartoons. In two of these cartoons, The Great Financier (Hawkins 1883, BM 4128 1765) and Goody Bull (Hawkins 1883, BM 4142 1766), amongst the caricatures goods lay on a dockside marked with broad arrows, probably to represent the produce of Britain that the colonialists had boycotted. The broad arrow thus found a new use in the rhetoric of political satire as a symbol of Britain or more specifically the British government and was aimed at amusing and informing the public and discomforting politicians.

\subsection{Summary}

The diverse applications of the broad arrow symbol illustrate that a symbol alone does not carry a specific meaning or imply a specific use. It is the customs and habits of users and abusers that set out specific practices that employ signs such as the broad arrow. Since customs and habits can be localised and fade with time so particular uses of, for instance, the broad arrow may only be prevalent for a limited period or within a particular cultural setting or geographical area.

Each application of the broad arrow engaged many people pursuing a variety of ways of life. A sign, such as the broad arrow, therefore is instrumental in the formation of a social network drawing together many individuals and practices. Sign making for example is an enterprise that requires a sign to be commissioned, designed, constructed, installed, maintained and authorised all of which may be taken on by an individual or, as with the broad arrow, furnished by an extensive network of individuals. A sign can therefore bring together many individuals and sustain a network of relations that, as with the North American use of the broad arrow sign on trees, are asymmetric.

\section{Analysis}

A broad arrow mark, like other arrow signs, is part of a socio-technological system with parts bound together by distinctive practices. As part of a system, an arrow sign bears relationships with 
other parts of the system. Commonly a sign provides connections between participants and connections between participants and objects and therefore an image of an arrow can play a part in forming relationships which may be many and varied. Relationships in sign systems have commonly been partitioned and reduced to a set of functions attributed to signs. Jakobson (1981) identified six types of functions of language, which can also be applied more generally to signs and the relationships they engender (Monk 2011). Notably, Jakobson introduced a poetic function which can accommodate the emotional responses of, for instance, the readers of broad arrow signs.

All six of Jakobson's functions are active in every situation where a sign is experienced though in different situations, with different signs or different people, the relative dominance of the functions can differ. The functions and their effects are also a product of a situation as well as the particular sign makers and sign readers. This implies that any general statements that are made by a commentator about the functions of particular signs (including statements made in what follows here) are speculative.

\subsection{Referential Function}

The referential function of a sign reveals what the sign is about. It centres on what a sign makers expected sign readers to do, but, of course, sign readers' responses do not necessarily match up to sign makers' expectations. The referential function can therefore be asymmetric with the obverse of the referential function recording the place of the sign in sign readers' ways of life. Figure 13 shows a sign where the expected action is made explicit. Sign readers should be in no doubt that they are expected to look both ways. Of course, the sign does not give any reasons for looking nor an indication of what to look for. These are assumed to be apparent to sign readers, who will relate the practices they are engaged in to the sign and its surroundings.

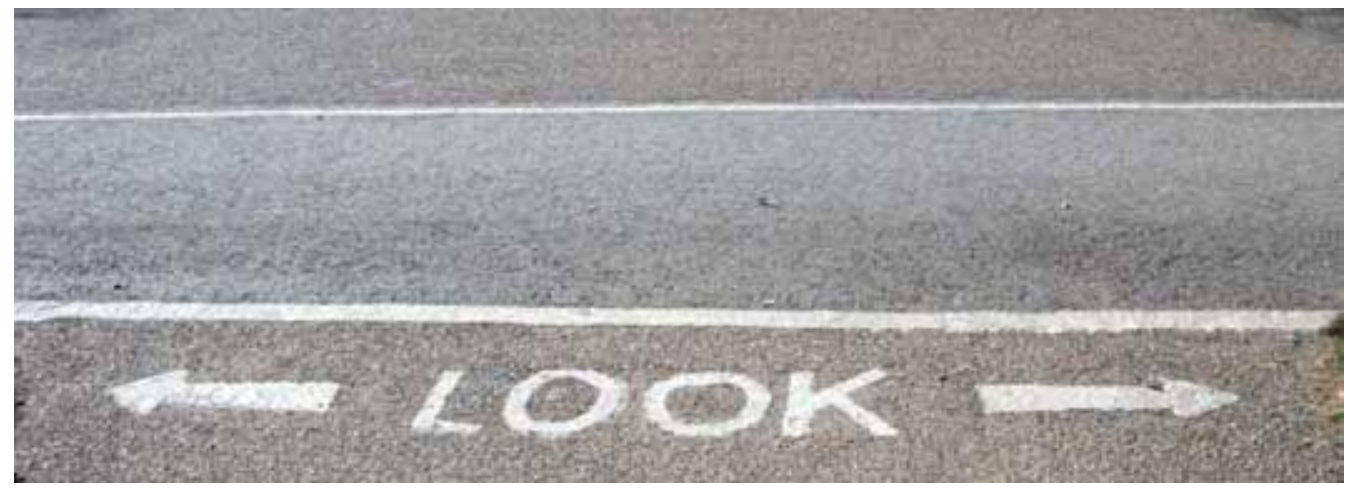

Figure 13: A sign with a clear statement of the sign writer's expectations.

For the English monarchy, the referential function of a broad arrow rested on the presumption that an object marked with the broad arrow would be taken to be the monarch's or the state's property and that the marked object would only be used in practices authorised by the king or queen. However the referential function could be appropriated by others, for example, counterfeiters might have hoped and expected others to be fooled into recognising the forged mark as an authentic sign indicating marked objects were the property of the King or Queen. And Maine woodsmen, whose sign readers were neighbours, adopted the sign to exploit the complementary referential function that indicated the marked object was not available to their neighbours and should be left alone. The woodsman effectively exploited the system of deterrence provided by the king's agents.

Agents of the Ordnance Survey put a broad arrow alongside each fiducial mark so surveyors would recognise the benchmarks as authorised indications of level. People who were not surveyors would know to leave the sign alone. By inscribing the broad arrow on manufactured goods, an authorised manufacturer signified a commitment to give up any claim to the goods and transfer ownership to the Crown and in prison the referential function of the broad arrow on clothing identified people as convicts who were expected to behave as convicts and be treated as convicts by others.

Thus a particular symbol, such as the broad arrow, does not carry a referential function; a range of referential functions are in effect determined by the practices that embrace the sign and ultimately the people that use signs either as sign makers or sign readers. 


\subsection{Expressive Function}

The expressive function articulates something about the sign makers or some aspect of the sign making enterprise. Corporate logos are dominated by their expressive functions. For instance, the retailing company Amazon has a logo that incorporates an arrow with a curved shaft in the shape of a smile pointing from the first $a$ in the company's name to the $z$ which the company claimed, emphasised "that Amazon.com offers anything, from A to Z" (Amazon.com 2000). A sign may also reveal something about the skill of the sign writer. Figure 14 shows a rudimentary sign hastily drawn. It probably indicates the sign writer was short of time and was limited by the materials to hand.

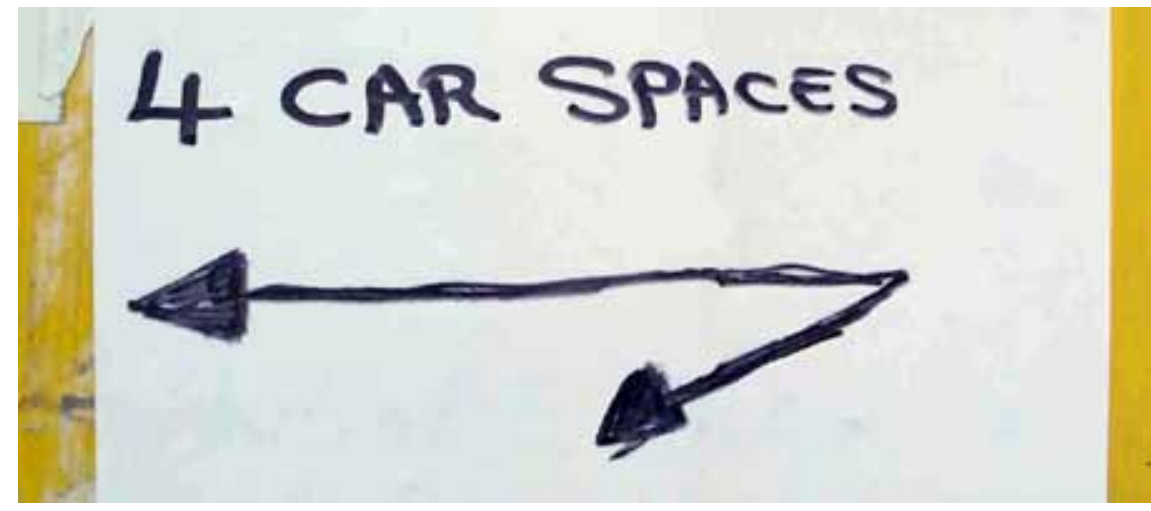

Figure 14: Hastily drawn arrows on a sign in London

A single broad arrow would reveal very little about an English monarch. A sovereign would delegate the minting of broad arrows so individual signs reflected something of the individual worker's approach to sign making. The monarch's attitude would be revealed in the collection of all arrows inscribed under regal authority together with the laws, proclamations, the existence of agents to police use of the arrow and punishments for particular actions. Rulers expressed themselves in the whole sign system. The existence of the broad arrow system suggests the regal authorities mistrusted their subjects and the geographical extent of the objects marked with the broad arrow was an indication of the monarch's reach. Since a king would project his wishes through a system of signs, punishments and detection, the brutality of punishment and zealousness of the policing would be signs of the monarch's emotional orientation. For the monarchy the broad arrow system was a statement about Royal rights and the declarations and laws expressed intolerance to infractions.

While the sign might be taken to stand for ownership by the king, the relationship with the King or the King's representative would depend on those encountering the sign and where they were situated. For the American colonialists, the authority that accompanied the King's mark was questionable but for an honest citizen in London the sign was an expression of a powerful regime. For the dishonest in London the broad arrow was probably recognised as a sign of an authority that could, with cunning, be evaded. Thus what the sign expresses about the authors of the sign depends on the individual sign readers, their practices, their locale and their personal history.

The Ordnance Survey had its agents who cut or cast benchmarks. The neat workmanship and uniform arrow symbols offered a public face of a well-regulated organisation. Obsolete benchmarks do not require maintenance but their state of disrepair might reflect on the agency that installed them and could tarnish its reputation; for instance, if a passer-by mistakenly believed the sign retained a functional role or had views on preserving a map-making heritage. That is, views on the organisation projected by the sign are partly a product of the sign readers' beliefs about the system. For instance, for the owner of property sequestered and marked by royal agents, the arrow may have signified an authority that was efficient in fulfilling its obligations, an authority that set challenges or one that made mistakes; the conclusion would have determined, for example, in the case of a ship's arrest, whether to abscond with the arrested ship or to surrender.

The requirement to wear distinctive and distasteful clothes would most likely have been seen by prisoners as evidence of a vengeful streak in their gaolers. A bystander might have seen the arrow on uniforms as a sign of an agency that runs an effective punishment regime while another onlooker saw the prisons as institutions, which, by insisting on tawdrily marked prisoner's clothing, engaged in vindictive practices. 


\subsection{Conative Function}

The conative aspect of a sign grabs the attention of sign readers and in many cases selectively addresses specific groups. It ensures those who are to be addressed notice the sign and those who are not be addressed know the sign is not a trigger for action by them.

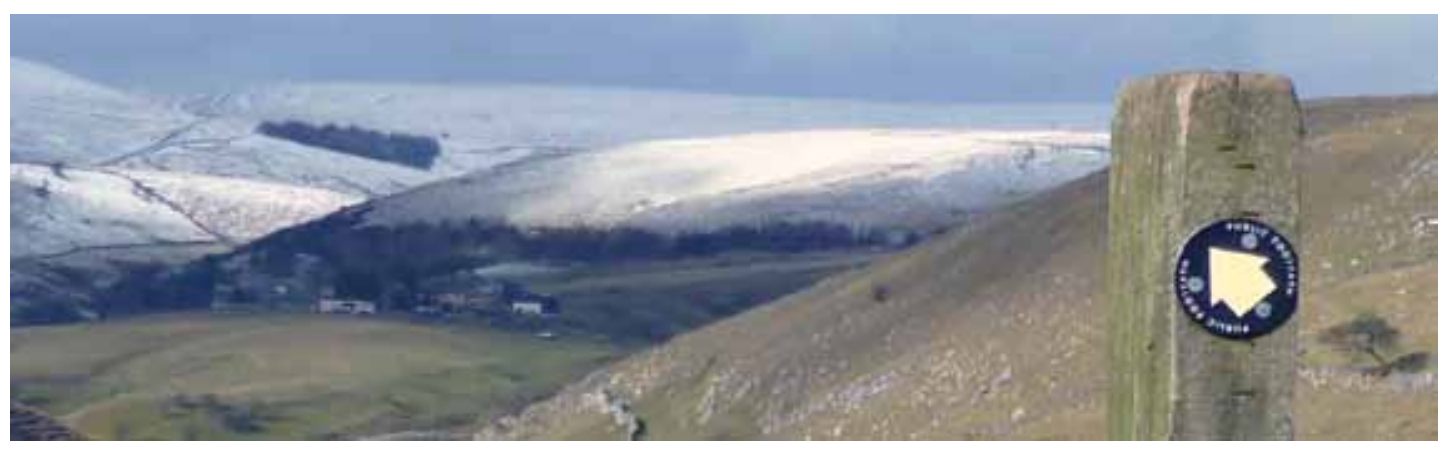

Figure 15: The colour of the arrow makes it stand out.

The picture in Figure 15 includes a yellow arrow sign which is prominent because of its colour and its position on a post. By convention in England, the colour indicates that the arrow is pointing to the route of a footpath (Ramblers 2012) and therefore the sign addresses walkers and not motorists, cyclists or horse riders. The prominent position and colour provide the conative function but only those who are familiar with the colour convention will grasp its full significance.

The conative function of a broad arrow relies on the distinctive shape, the symbol being in a prominent place and in a place where the arrow cannot be confused with other functional parts of the object it marks. The Defence Standard on marking goods, for instance warns that an arrow marking goods "should be so positioned that it does not point in a direction which could be construed as indicating the direction of rotation of instrument pointers, direction of flow of liquids or gases, or direction of movement of mechanical parts" (MoD 1984, 26) and so muddled with arrows used in other sign systems and their related practices.

Fellers in colonial North America, as part of their trade, would have learned to look out for the broad arrow sign and those policing the sign would certainly have been familiar with it.

In prisons the purpose of adding the arrow was to make it clear someone was a convict so the arrows on the clothing would have been bold and the clothing distinct from any other patterned garment.

\subsection{Phatic Function}

The phatic aspect of a sign encourages the formation of connections between separated signs so they are taken as one sign. Figure 16 is a sign spotted in a hotel corridor. It has two major components. To the left the up and down arrows are united by their similar styles which are distinct from the style of the third arrow. The pair of arrows together with the box containing the two figures are commonly taken to be a sign for a lift/elevator with the up and down arrows indicating the up and down movement; this is the grammatical object of a graphical sentence. To the right and on the same substrate, is a second upward pointing arrow which, in this case, gives a clue to the location of the actual object, the lift/elevator that is beyond the sign and by convention along (not above) the corridor. The rightmost arrow acts as an imperative verb. In this case the phatic function is provided firstly by the sign's substrate which unites the sign's components. Secondly, the location is implicitly part of the sign and the single upward pointing arrow would lose its utility if the sign were moved, so the sign is bound to its location by being screwed to the wall. Thirdly, the relative positions of the sign's implicit subjects, the readers, matter; for instance they must face the sign for it to be of use; as a result the phatic function is dependent on potential sign readers' relative positions and their individual desire to find a lift/elevator. The arrows on the sign in the centre of figure 16 are all of a similar style and the phatic function binding the two arrows for the lift/elevator is achieved by their juxtaposition and enclosure.

The numerals on the traffic sign to the right of figure 16 provide a link with buses that carry the same numerals. The sign provides connections with the drivers who are aware of their own bus's number, and therefore discriminates between bus drivers who are supposed to take note of the 
sign and those who are not. Such recognised cross-references between numerals on the sign in the street and on buses also form phatic functions.
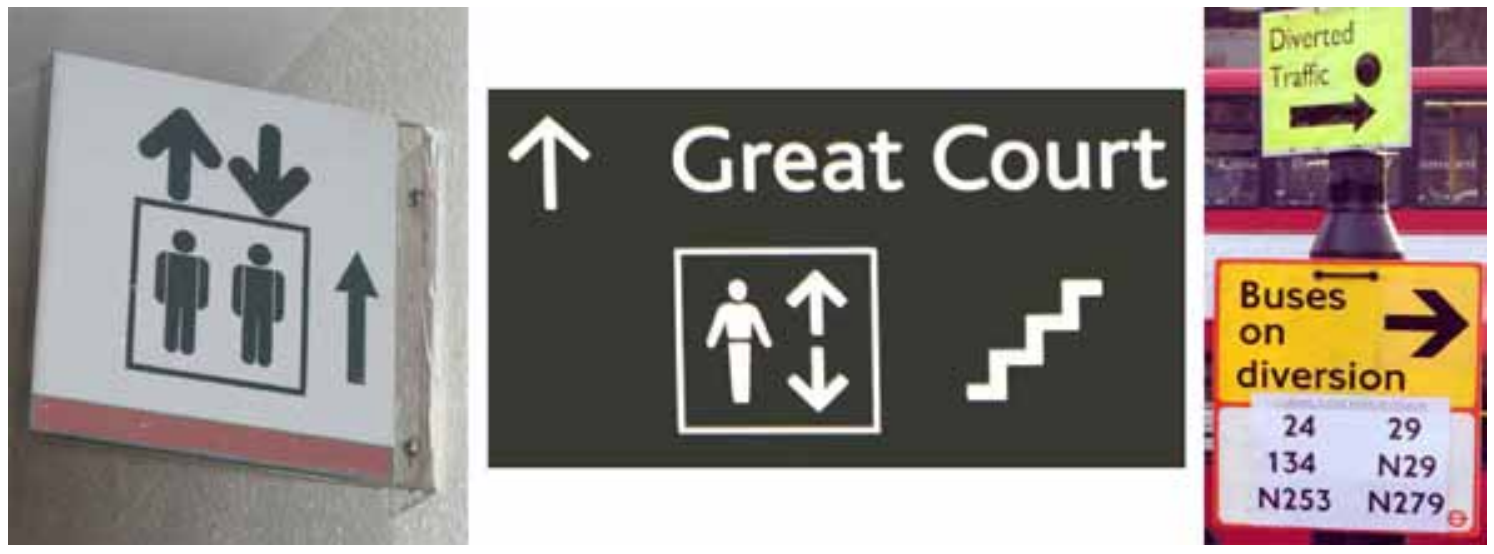

Figure 16: On the left is a sign composed of two distinctive parts bound by the common substrate. The sign in the centre uses arrows with a similar style to one another. On the right is a sign providing a link to specific bus numbers.

As a mark of royal property, the broad arrow was inseparable from its substrate; a tree, a plank or a canon barrel, for example. The broad arrow symbol was therefore bound physically to the proprietary object. The significance of a specific arrow was therefore related to a specific object. Strictly, removing the arrow does not change the status of the object nor does transferring it to another object however in practice skilful attempts at destroying the phatic function would remove any identification and more than likely cause a de facto transfer of ownership. A broad arrow provided the connection between an object and the royal authorities. The phatic function of the arrow therefore included a binding between the broad arrow and the King's authority relayed to sign readers probably by scant direct experience and accounts and rumours of incidents which could in some instance be fabricated and therefore be in the form of moral tales. Self-identification with the characters in the tales and the attitude towards the emblematic sign readers in those tales potentially influences an actual sign reader's perception of the sign's phatic function.

The Ordnance Survey's broad arrow and its accompanying survey line are physically bound together by their common substrate. The broad arrow also indicates that data about the survey point is held in an official index. That is the arrow announces or binds the survey point with a volume of data held elsewhere. Specific data for a particular benchmark is indexed according to the position of the benchmark thus the locations of the benchmarks are part of the sign system and the immobility of the benchmarks' substrates is an important ingredient of the sign system.

The binding of the convicts to the broad arrow was simply provided by the prisoner wearing marked clothes. Prison rules, prison discipline and the lack of an alternative secured the garments in place on the prisoner's bodies.

In all cases, physical arrangements and symbols give hints on bindings but an association ultimately is recognised by those who read the signs; that is bindings are themselves symbolised, for example, by juxtaposition. The broad arrow, it could be argued, was dominated by its phatic function which for sign readers connected an object with an authority.

\subsection{Meta-lingual Function}

The meta-lingual aspect of a sign assists in the translation of a sign or part of a sign into other signs usually to help sign readers who are unfamiliar with the original sign's conventions. It provides a degree of redundancy. Figure 17 provides an example. The figure is a fragment of a map of Venice with the arrow indicating the orientation of the map. Mapping conventions have the arrow head pointing north so strictly the initials $\mathrm{N}$ and $\mathrm{S}$ are not needed. They are meta-lingual elements to assist those who are unsure of the arrow's use. The addition of the monarch's initials or other royal symbol alongside a broad arrow, on canon barrels for example, added redundancy and provided a meta-lingual function. 


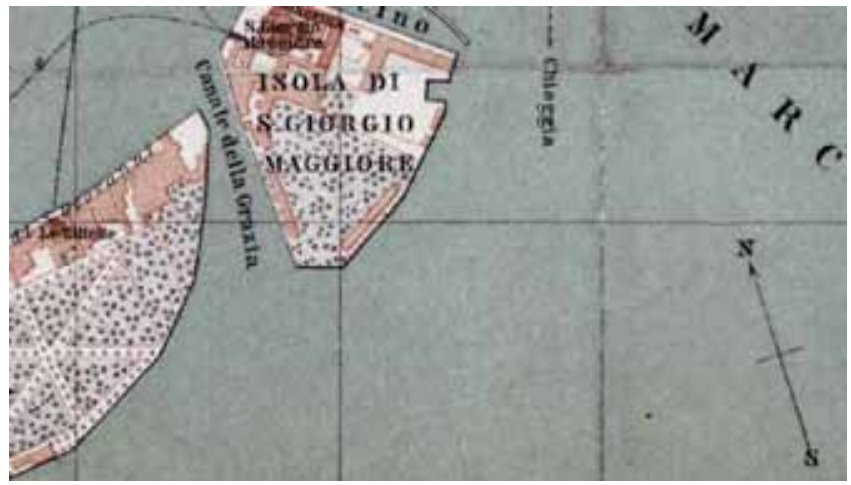

Figure 17: A piece of a map of Venice with an arrow showing the orientation of the map (Anon. 1886)

However without such meta-lingual elements anyone unfamiliar with the mark, for instance on pewter work would be ignorant of what to do if they noticed it. In effect it was the laws, proclamations, accounts of events, observations rumours and gossip, or in the case of a pewter craftsman an apprenticeship, that provided the meta-lingual elements that familiarised people with the use of the broad arrow. Thus declarative practices surrounding the sign system create meta-lingual cues.

\subsection{Poetic Function}

A poetic function accommodates the resonances that words, shapes, colours and arrangements on a sign have with similar words, shapes, colours and arrangements in other settings - resonances that provoke responses and create tensions with the responses invoked by other functions of the sign.

The sensual image of a situation can on occasions be seen as an invitation to action. Thus a sign gains its power by modifying a situation to arouse (or inhibit or regulate) action in particular ways. Objects, artefacts, shapes, symbols, words, colours and signs have affordances, that is they invite specific reactions. They have a history of literary, semiotic and physical use which can infect new uses. For example, arrow signs and the word arrow are infected by the shape, properties, history and tales and uses of physical arrows. An element of a sign that comes with a rich set of affordances, such as an arrow, can present what might otherwise require an arrangement of several graphical or verbal elements just as a literary metaphor can express what would otherwise be tedious, cumbersome or impossible to state. However, a rich set of affordances can generate ambiguity and confusion when it is unclear to the sign reader which affordances to adopt. Figure 18 shows two diagrams taken from a single plate in a paper by Faraday where various arrows with a similar appearance have different uses and belong to different systems of signification. The metalingual clues given in the accompanying text, in this case, disambiguate the arrows' roles.
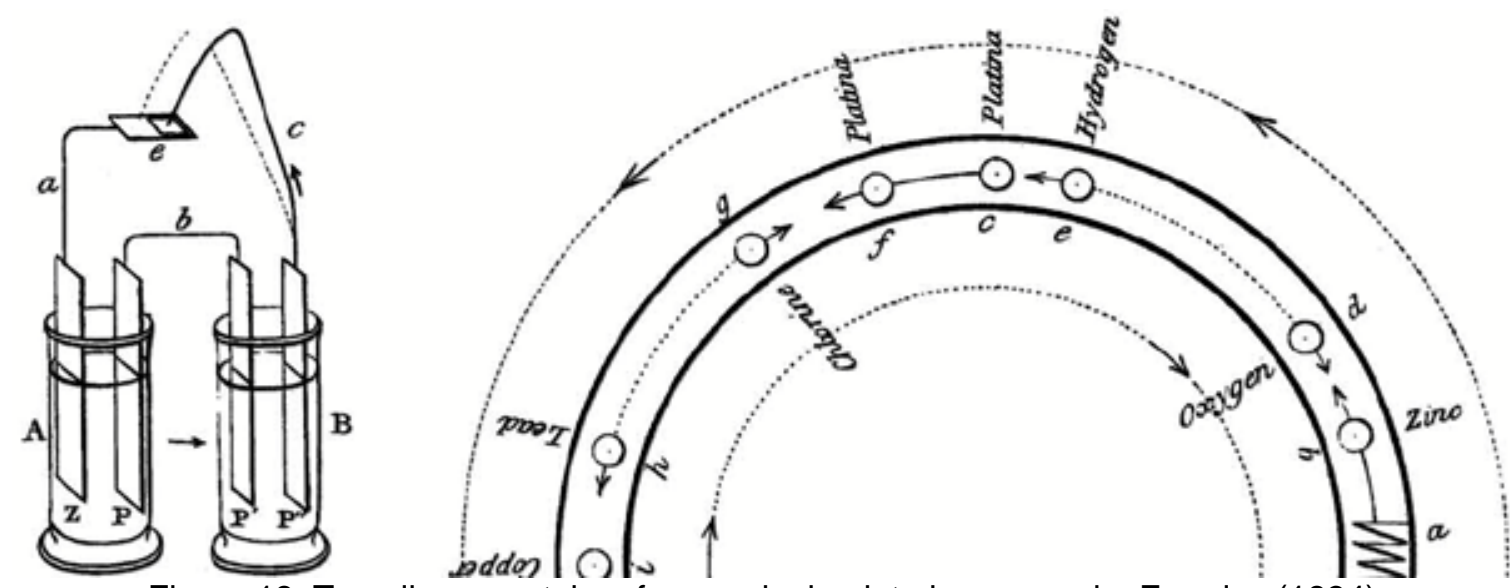

Figure 18: Two diagrams taken from a single plate in a paper by Faraday (1834).

Literary metaphors and similes hint at possible poetic functions for arrow signs. Physical arrows fly point first and this directionality leads to a useful literary simile; for instance, a verse in the 1611 
edition of the King James biblical apocrypha emphasises that a plague will not return by creating a comparison with an arrow which when "shot of a mightie archer returneth not backward" (Esdras 1996). Arrows also evoke sensations of movement at speed as when Andrewe (1527) describes an eagle's descent to pluck a fish from water as "swyft as an arowe out of a bowe". Sureness is alluded to in the Fletchers' company motto - "true and sure" (Sanders-Hewett 2004, 11). Directionality is also exploited in the use of images of arrows. Figure 19, for example, is a part of a hydraulic system that is described in a paper by Charles Babbage. In the paper he did not mention the arrow; he takes it for granted that readers will be aware of the arrow's affordances and interpret the arrow as indicating both movement and the direction of flow of water in the pipe.

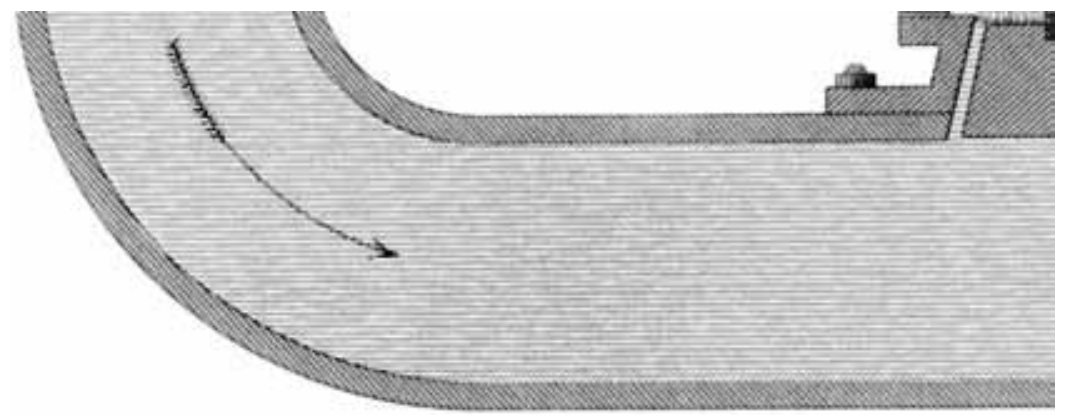

Figure 19: A part of a hydraulic system with an arrow showing the direction of flow (Babbage 1826).

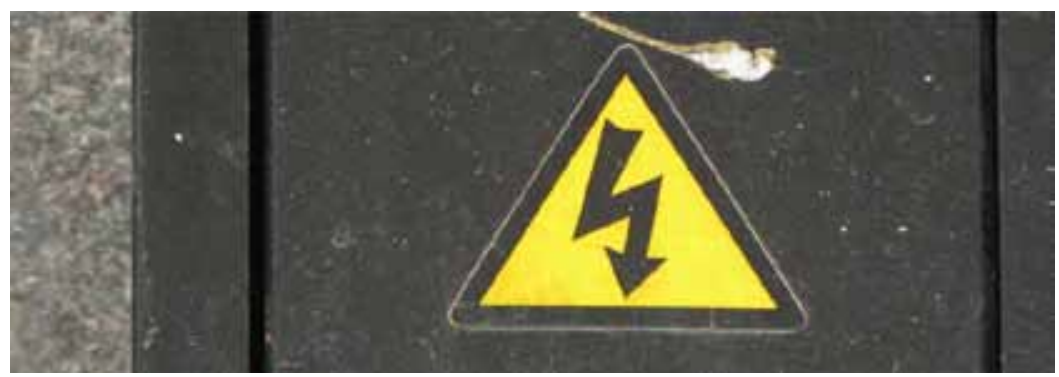

Figure 20: An arrowhead on a lightning strike warning of the danger of electrocution.

Other references use the wounds inflicted by arrows as similes, for example, likening the harbouring of an insult with "an arrowe that sticketh in a mans thigh" (Ecclesiasticus 1996). The arrow's capability to harm is also metaphorically exploited on the sign in figure 20 warning of the danger of electrocution.

The poetic function introduced by Jakobson operates in the space offered by the variety of ways of materialising referential and other functions. After fulfilling the other functions of a sign, for example, ensuring a sign commands the attention of the intended audience and withstands its ambient conditions, sign makers can inject individual preferences bounded only by the available space, tools, skills and materials. As Pepys remarked, the admiralty could have chosen an anchor rather than an arrowhead or even kept the broad arrow symbol and called it an anchor.

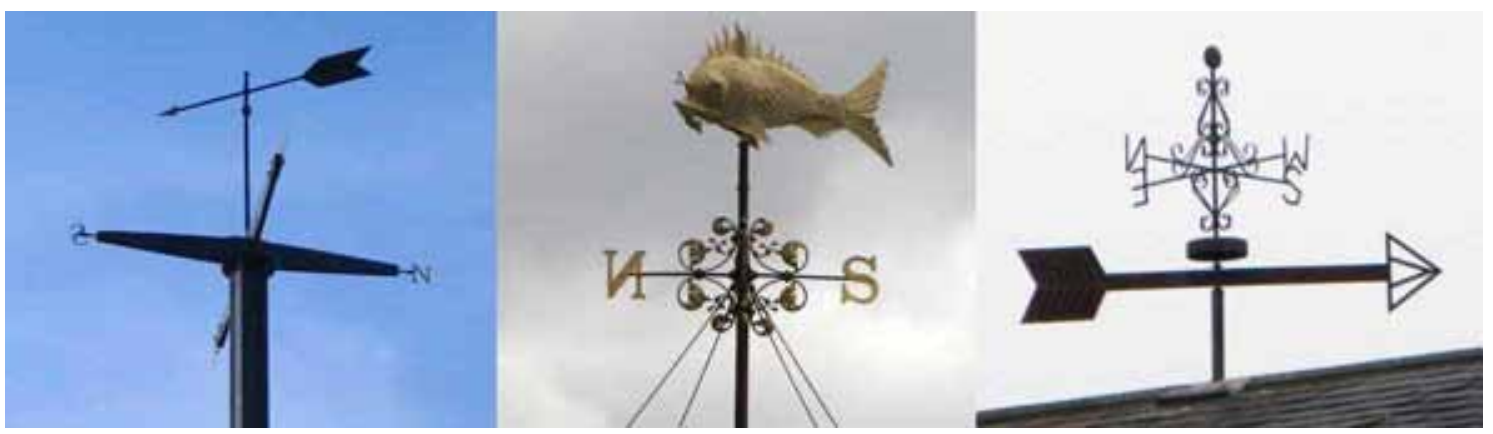

Figure 21: Three weather vanes with different shaped pointers 
Figure 21 illustrates the choices sign makers have. The figure shows three serviceable weather vanes with identical referential functions but with different shaped indicators; one is fish-shaped and therefore offers a poetic function provided by a metaphorical connection to imply a direction, which differs from the metaphor provided by the arrow shaped vanes that connect the wind with the forms of arrows in noiseless flight - some with more grace than others. For some purposes a manicule, a pointing fist, is an alternative to an arrow or arrowhead. Manicules are found in medieval documents (Sherman 2005) to highlight parts of texts and as figure 22 shows there are continuing uses for manicules on signs indicating directions.

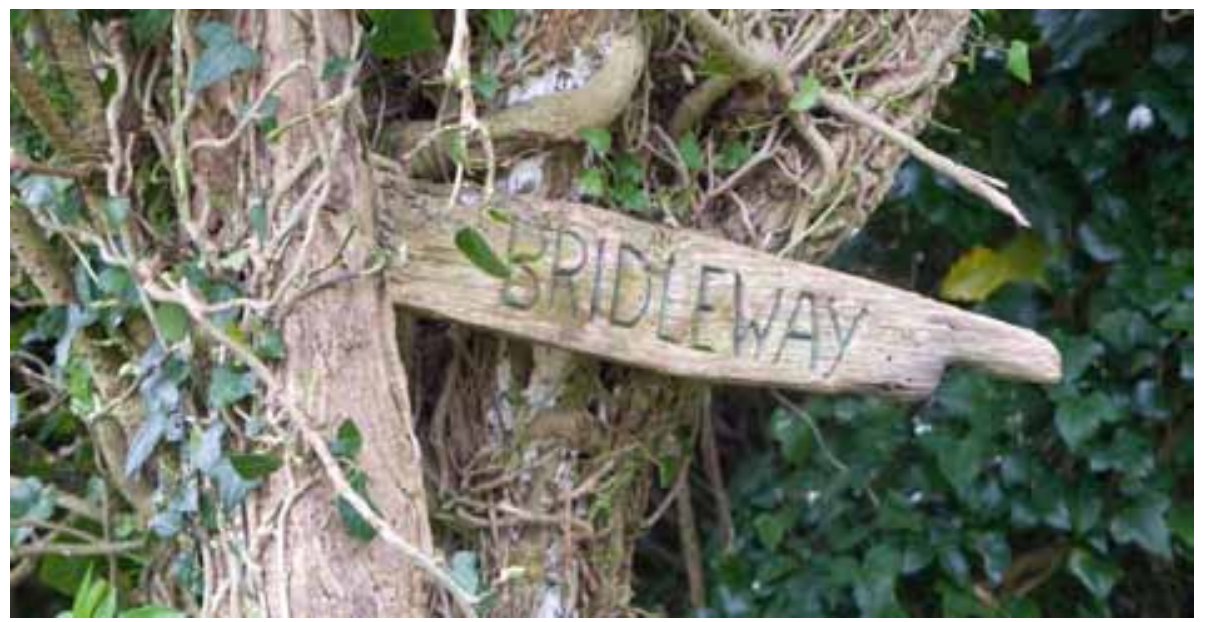

Figure 22: Finger post directing walkers, cyclists and horse riders. (Buckinghamshire, UK)

Since there are options, sign makers can choose the forms that are appropriate to the practice that the sign belongs to. Thompson $(1878,10-11)$ demonstrated that literary choices can be good or bad - apt or inappropriate. He gave a list of similes and highlighted their durability as poetic elements writing, "'Sharp as an arrow," "Swift as an arrow," "Straight as an arrow," "The shafts of envy, love, hatred, or revenge", etc., are expressions as common to the verse-makers of our own time as to those of Pindar and Homer". He then took exception to other examples which did not refer to arrows and therefore had different affordances which he considered rendered the similes and metaphors distasteful. He argued, "Straight as a ramrod," "Swift as bird-shot," "The buck-shot of envy," or "The cartridges of malice" would be thought expressions or phrases of very questionable propriety"

Convention dictates the arrow in figure 23 , for example, would be taken to point the way but other shapes, such as the manicule shape in figure 22, could have been chosen; nevertheless the association of the image with the imagined flight of a physical arrow makes the choice an apt one.

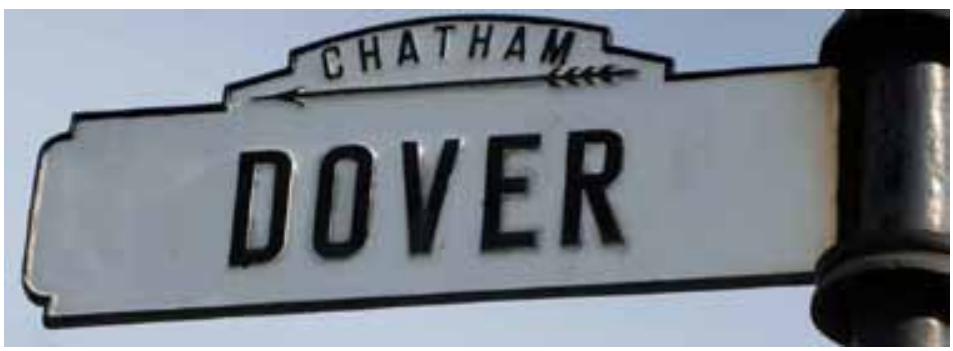

Figure 23: An arrow indicating the direction to travel to get to a named town.

Leja $(2001,490)$ described a particular sketch of a seven spoked "wheel [...] set into clockwise motion by an arrow at its perimeter". Leja continued, "As [ . . a a pointer signifying directional movement, the arrow eliminates the need for blurred spokes". Thus Leja indicated there are different conventions for signalling motion in a static picture. Blurred spokes interfere less in a picture's naturalism but adding an arrow makes the picture appear to be part of a technical study or technical explanation, which was in keeping with the sketch that Leja mentions since the wheel and arrow 
were drawn on the frame of a portrait of a physicist: Henry Rowland accompanied by one of his inventions.

Charles Babbage aimed to describe the movements of parts of machines but admitted he found "ordinary language [...] far too diffuse" $(1826,251)$ so, because of its ability to condense descriptions, he resorted to "the language of signs". Babbage then explained, "The sign which I have chosen to indicate this transmission of motion (an arrow), is one very generally employed to denote the direction of motion in mechanical drawings; it will therefore readily suggest the direction in which the movement is transmitted" $(1826,253)$.

Thus he chose the arrow because of its history in describing motion but it was nevertheless a choice and he could have chosen a different symbol which would have different affordances.

The availability of choice lays open the sign maker to criticism of the choices they actually make. For instance, in Britain in 1929, there was considerable interest in the standardisation of traffic signs. Prototype designs of signs showing people where to cross the road were challenged by The Royal Fine Art Commission, which "criticized the old-fashioned design for [...] 'needlessly reinforced' arrow shafts and 'the barbs and quills of the arrow' that had to be 'simplified"'(Suga $2003,176)$. This was clearly a matter of opinion, in this case tied up with a modernist ideology and thus potentially a topic for hostile irresolvable debates. In such cases a sign can clearly provoke a strong emotional response.

The eminent artist, Paul Klee, famously incorporated arrow shapes into his pictures. Klee's use of arrows shows that arrow shapes and their colouring in association with other graphical components can excite responses in the sign reader beyond a cold visual sensation of shape. The section of his lecture notes entitled "Symbols of Form in Motion" is in part dedicated to showing how arrows might be used in visual art. Elsewhere in the notes arrows convey motion, force or conjure up a third dimension. Figure 24 is an example of Klee's work with black arrows that seem to be captured in flight. In his lecture notes Klee was explicit about the affordances of a specifically black arrow and wrote, "the arrow always flies in the direction of action [...] the contrasting peculiarity of sudden action (black) sharpens the vividness of vision toward the climax or the termination of this action" (Klee 1972, 57)

Leibowitz and Hoffmann $(1991,17)$ explained "Klee constructed his universe in terms of tensions or balances" with the arrow as a "symbol of this tension, whether it is physical or within the psyche" $(1991,18)$. For spectators, the arrows in Klee's painting do not necessarily have an obvious referential function but do support a particular practice, art, that deliberately provokes emotional responses; thus Klee's arrows are dominated by their poetic function.

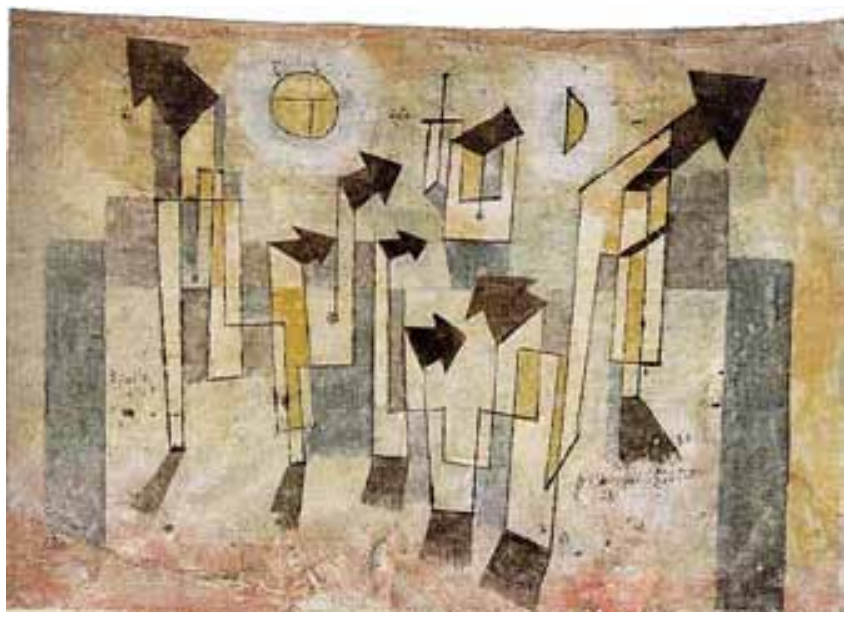

Figure 24: Wandbild aus dem Tempel der Sehnsucht $k$ dorthin $\rightarrow$ (Mural from the Temple of Longing $*$ thither $\rightarrow$ ). Painted by Paul Klee (1922).

The poetic function of the broad arrow would be felt in different ways by the different actors and it is impossible to know how, but it is possible to speculate on what emotions might be stirred by signs. Whatever the affect, it would probably be related to the practices and the role of the sign reader. For pewter workers, who had their work stamped and forfeited, the broad arrow must have been a source of irritation. For the felon the broad arrow on valuable goods was a reminder of the possibility of arrest and punishment and might have caused some anxiety, and people without a specific role might still have experienced some unease if they encountered the broad arrow mark or 
found themselves handling marked goods because of stories of arrests they may have heard. A captain who had the broad arrow stamped on the mast of his ship would likely be angered and frustrated by sight of the mark.

Arrows can be portrayed, as Klee did, so that they hint at movement. Alternatively, lacking a shaft and a tail and commonly pointing directly upward on marked goods, or in English heraldry pointing downwards, the broad arrow head appears static. The pictures of Ordnance Survey benchmarks illustrate the opportunity for the use of different materials and different shapes in portraying an arrow. The attachment to a robust and permanent structure adds to a feeling of stability appropriate to a reference point. Additionally, pointing upward and blocked by the surveyors fiducial marks, the Ordnance Survey arrowhead lacks a sense of movement that might come with an unconstrained horizontal fletched arrow.

Those convicted and imprisoned under the broad arrow regulations may have felt remorseful, dispirited and demeaned when they encountered the sign day after day inseparable from their individual selves. For the colonialist a broad arrow would have stirred up anger and frustration which became in some cases an incitement to violence; it would have been a provocative reminder of an unsatisfactory constitutional position, an attribute that led Tolles $(1954,6)$ to write of the broad arrow as an "emotion-laden symbol".

\subsection{Multifaceted}

Jakobson's six categories show that signs, or rather the responses of sign readers to signs, are multifaceted. The picture to the left of figure 25 shows the sign of figure 13 in a wider context. Aside from the referential function which makes people aware of the possibility of traffic from both directions, the expressive function is evident since the sign demonstrates that the sign makers cared about the safety of the sign readers. The orientation of the word, the boldness of the sign and the sign's position all perform conative functions drawing the attention of pedestrians on the path. The arrows are likely to be seen as part of the same sign by their similar style, size and colour characteristics that provide a phatic function. Because of its situation on a footpath next to a road the word "LOOK" is likely to be redundant for many pedestrians. "LOOK" (or possibly the arrows) therefore provides a meta-lingual function. The poetic function is revealed when the sign on the left of figure 25 is compared with the sign to the right which performs a similar referential function (except the warning is for traffic in one direction only) but has a radically different appearance and illustrates that in both instances the sign makers had choices available to them.
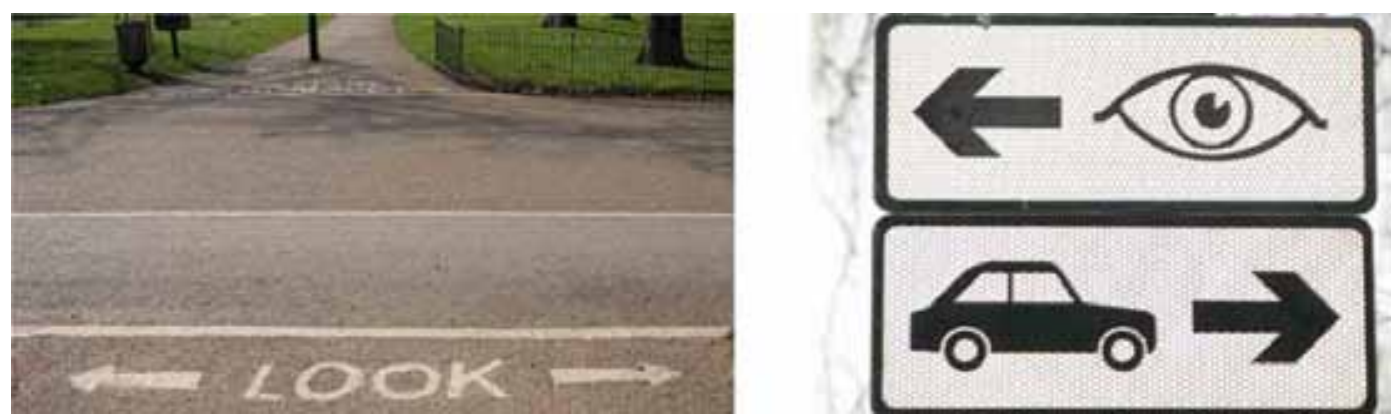

Figure 25: On the left the sign of figure 13 with some context. On the right a sign with a similar referential function to the sign in figure 13.

Each arrow sign exhibits several functions and the number of functions can be multiplied by the situations and the stances of the sign makers and the potential multiplicity of sign readers. Edmund Clark's (2010) photograph of an arrow on the floor in the Guantanamo detention facility entitled "Camp Four: arrow pointing to Mecca and ring for ankle shackles" hints at the complex of relations that can revolve around a single arrow sign and indicates how the geographic, temporal and cultural context might affect the perception of the sign's functions for different observers, such as the captives, the captors, the photographer and the photograph's viewers.

\section{Conclusion}

Arrows have been used as weapons in many cultures. They fell out of use in England centuries ago yet in debates over their decline they gained a glorified mythic status which has kept alive an acquaintance with their behaviour and knowledge of their various shapes. 
Signs have incorporated arrow images from the time of their early monarchical use to today when signs commonly exploit a metaphoric connection with the characteristics of physical arrows; while some semiotic applications simply appropriate other uses of the image, as in cartoons, or adopt their use, like the sign for authorised survey points which was derived from of the Board of Ordnance's broad arrow emblem.

What made arrow images on signs useful were extensive social arrangements. Applications of the broad arrow show artefactual signs are situated within socio-technological systems, and within such a system an individual sign is a point of convergence for a variety of practices - at the very least the distinctive practices of an individual sign reader and an individual sign maker.

To say a physical image of an arrow plays a part in a sign reader's practices implies the sensual image prompts or restricts action; a sign is therefore a political device and the deployment of a sign is an attempt to influence the ways of life of the sign readers. Thus a sign, like a present-day arrow sign directing drivers of vehicles, modifies its specific environment to invite (or inhibit) action. Where a sign has become an accepted component of a way of life, the material properties of the sign, for instance its durability and its spatiality together with the acquiescence and habits of the sign readers, aid sign makers in projecting their authority across time and at a distance. Although a sign making enterprise governs where and when a sign is deployed, each sign reader determines how a sign is used. For example, the intention behind the introduction of the broad arrow in North America, did not match the well-established ways of life of the settlers and efforts to enforce a specific use bred resentment; it did alter ways of life and the political climate but not as the sign makers intended. The effectiveness of a sign therefore depends on the integration of the sign into the sign readers' ways of life in the manner the sign makers anticipated. A sign maker can be an individual with a clear expectation of the effect of the sign. However sign making can be an enterprise potentially on a national scale with different groups responsible for constructing, deploying and designing the sign with others standing for the authority behind the sign possibly aided by associates regulating a sign's use and penalising its abuse. In such cases the potential variety of expectations is liable to generate an assortment of views on a sign's efficacy. If ready acceptance seems unlikely sign makers could engage in the metaphorical use of images of commonly known artefacts, images described in commonly told moral tales or appropriated forms of existing signs which have already found a place. They might also try instruction, propaganda or even coercion.

All readers will not respond in the same way to a sign. Some North American loggers, for example, had little regard for the broad arrow but were able to reserve timber for themselves by appropriating the symbol and exploiting the respect shown towards the sign by other settlers. Additionally, signs with a similar appearance and deployed with similar intentions will be in different locations and potentially at different times when different physical or social circumstances could affect readers' responses. In most cases an individual sign will be part of a close family of signs expected to be part of a widely adopted practice, however each sign will be a part of a different situation and each sign reader will have a different personal history. For example the archaeologist's response to the same broad arrow would have been different to a receiver of stolen goods several centuries earlier. Thus a fine grained analysis must accommodate such differences or at least the types of differences. There is therefore nothing inherent in a sign that leads to specific universal uses; the broad arrow signs, for example, were instrumental in a range of practices which had different political, geographical, temporal and cultural bounds.

A thorough analysis of the role a sign has to take account of the different interests and practices of the individuals involved in its creation and the individuals that encounter it. Jakobson's identification of six functions provides an initial partitioning of a sign's effects which colour the relationships between those connected with a sign. However Jakobson's framework does not in itself encourage consideration of the plurality of the ways of life of sign readers or those employed in the enterprise of sign making. Jakobson's referential function, for example, reveals how people encountering a sign are expected to behave. However, there is no guarantee of congruence between the reactions of different sign readers or between the reaction of a sign reader and the expectations of those creating and deploying the sign. There is therefore a potential multiplicity of referential functions associated with a single sign.

The expressive function tells something of the attitudes of the sign makers. The expressive function treats the sign as a medium through which a reader views those who create signs. Again there will be a multiplicity of views each affected by the perceived roles of the individual sign makers and accounts of the sign makers within an individual sign reader's cultural history. The conative function gives the sign prominence and ensures it is recognised by the intended audience. An effective conative function requires the sign makers to be aware of the sign's physical situation and the symbols of the addressed sign reader's self-identity. The phatic function enables the linking of 
sign components possibly in close proximity to one another or potentially distributed in time and space; it holds the components of a sign together through physical and socially derived bonds. Complementary measures to separate signs imply an effort to explicitly select and situate sign elements so that there is no evident phatic function at play. The meta-lingual function plays a more technical role; it broadens the potential audience for a sign by providing a translation of elements of a sign into the vernacular of those whom the sign might address.

A specific benefit of Jakobson's work is that It took a step away from utilitarian considerations and introduced the poetic function, which encourages analysts to include consideration of the emotional response of sign readers to a sign - a response that could provoke accidentally or deliberately emotional distress. Such effects introduce an ethical dimension to the study of signs. However, the damage to self-respect was not the product of the arrow painted on prison uniforms but a product of the practices that incorporated the arrow. Similarly the provocations provided by the arrows on trees in North America were the result of integrating the broad arrow into unreasonable systems of ownership.

To say that something, such as an image of an arrow, provokes an emotion or provides or carries information is to say that something is a sign and is therefore instrumental in a practice or way of life of a sign reader. Emotions, functions or information attributed to a sign are therefore products of an activity rather than the enduring meaning of a symbol. While a sign's functions are presented as properties of a sign and determined by the sign makers, it is the individual sign readers who react to signs and who establish the dynamics and the use of the sign system. Signs do not have meanings but they do come to provide cues to actions or inaction within social practices that have moral dimensions. It is not that signs can be offensive but that signs become instrumental in practices that can arouse emotions and in some instances can offend.

\section{References}

A.C.M. 1851. The Broad Arrow. Notes and Queries s1-IV (108): 412.

A.F. 1925. The Broad Arrow. Notes and Queries 149: 153.

Albion, Robert Greenhalgh.1926. Forests and Sea Power. Cambridge: Harvard University Press.

Alvarez, Santiago. 2012. Chemistry: A Panoply of Arrows. Angewandte Chemie International Edition 51 (3): 590-600.

Amazon.com 2000. Amazon.com Introduces New Logo: New Design Communicates Customer Satisfaction and A-to-Z Selection. Press release January 25. Seattle: Amazon.com.

Andrewe, Laurens (trans.) 1527. The Noble Lyfe a[nd] Natures of Man of Bestes, Serpentys, Fowles a[nd] Fisshes [that] Be Moste Knoweu. Antwerp: John of Doesborowe.

Anon. 1765. The United Voice of All His Majesty's Free and Loyal Subjects in AMERICA, LIBERTY and PROPRTY, and No Stamps. The New York Gazette or the Weekly Post-Boy 1198: A.

Anon. 1846. The Convict System: Economy of the Hulks. Illustrated London News 199: 125.

Anon. 1851. Broad Arrow or Arrow Head. Notes and Queries s1-IV (104): 315.

Anon. 1878. Five Years' Penal Servitude by One Who Has Endured It. London: Richard Bentley \& Son.

Anon. 1886. Venezia. Leipzig: Geograph. Anstalt v. Wagner \& Debes.

Anon. 1895. New London: Her Parliament and Its Work. LSE Selected Pamphlets. London: Edward Lloyd: 41-44.

Anon. 1910. The Convict's Days of Labour and Day of Rest: In Portland Prison. Illustrated London News 3726: 427.

Armstrong, Robert. 1720. Letter to Charles Burniston Nov 20. In Calendar of State Papers Colonial, America and West Indies, Volume 32, edited by Cecil Headlam, 231. London: HMSO.

Armstrong, Robert. 1721. Letter to Charles Burniston Oct 20. In Calendar of State Papers Colonial, America and West Indies, Volume 32, edited by Cecil Headlam, 469. London: HMSO.

Armstrong, Robert. 1722. Letter to Charles Burniston 25 July. In Calendar of Treasury Papers, Volume 6, edited by Joseph Redington, 149. London: Longmans, Green, Reader, and Dyer.

Ascham, Roger. 1545. Toxophilus the Schole of Shootinge Contayned in Two Bookes: To All Gentlemen and Yomen of Englande, Pleasaunte for Theyr Pastyme to Rede, and Profitable for Theyr Use to Folow, Both in War and Peace.

Babbage, Charles. 1826. On a Method of Expressing by Signs the Action of Machinery. Philosophical Transactions of the Royal Society of London 116 (1/3): 250-265.

Beaton, Cecil Walter Hardy. 1942. Winged Squadrons. London: Hutchinson.

Berry, William. c1830. Encyclopædia Heraldica. Vol. III, Plate IX. Sherwood, Gilbert and Piper.

Bradridge, C. K. 1925. The Broad Arrow. Notes and Queries 149 (oct17).

Bridger, John. 1708 Letter to Council of Trade and Plantations July 6 1708. In Calendar of State Papers Colonial, America and West Indies, Volume 24, edited by Cecil Headlam, 19-20. London: HMSO.

Bridger, John. 1710 Letter to Mr. Popple July 26. In Calendar of State Papers Colonial, America and West Indies, Volume 25, edited by Cecil Headlam, 141-142. London: HMSO.

Bridger, John. 1711. Letter to Lord Dartmouth May 21 1711. In Calendar of State Papers Colonial, America and West Indies, Volume 25, edited by Cecil Headlam, 524. London: HMSO.

Bridger, John. 1718a. Letter to Council of Trade and Plantations July 14 1718. In Calendar of State Papers Colonial, America and West Indies, Volume 30, edited by Cecil Headlam, 307-308. London: HMSO.

Bridger, John. 1718b. Letter to Mr. Popple July 14 1718. In Calendar of State Papers Colonial, America and West Indies, Volume 30, edited by Cecil Headlam, 310-311. London: HMSO.

Brockman, Bennett A.1983. Children and the Audiences of Robin Hood. South Atlantic Review 48 (2): 67-83. 
Burrowes, William, and Thomas Taylor. 1670. Report to the Navy Commissioners July. In Calendar of State Papers Domestic: Charles II, 1670: With addenda 1660-70, edited by Mary Anne Everett Green, 350. London: Longman, Green, Longman, \& Roberts.

Carlton, William A. 1939. New England Masts and the King's Navy. The New England Quarterly 12 (1): 4-18.

Carus, Carl Gustav. 1846. The King of Saxony's Journey through England and Scotland in the year of 1844, translated by S. C. Davidson. London: Chapman and Hall.

Charles II. 1629. The Charter of the Massachusetts Colony Reproduced in A copy of the Kings Majesties charter, for incorporating the Company of the Massachusets Bay in New-England in America granted in the fourth year of His Highness reign of England. Boston: Benj. Harris.

Charles II. 1661. A Proclamation for Prohibiting the Imbezlement of His Majesties Stores for Shipping. Blackfriars: The King's Printing House.

Churchill, Winston Spencer. 1920. Letter to the Cabinet on the Government Marks Bill. London: War Office.

Clark, Edmund. 2010. Camp 4, Arrow Pointing to Mecca and Ankle Shackle Ring: Guantanamo If the Light Goes Out: Day 6. Accessed July 14, 2012. http://www.ifthelightgoesout.com/\#/6

Colquhoun, Patrick. 1797. A Treatise on the Police of the Metropolis. London: H. Fry.

Cotton, Charles. 1674. The Compleat Gamester, or, Instructions How to Play at Billiards, Trucks, Bowls, and Chess Together With All Manner of Usual and Most Gentile Games Either on Cards or Dice: To Which Is Added the Arts and Mysteries of Riding, Racing, Archery, and Cock-Fighting. London: R. Cutler.

de Voragine, Jacobus. 1483. Legenda Aurea Sanctorum, Sive, Lombardica Historia, London: William Caxton.

Dunbar Jeremiah. 1729. Letter to Col. David Dunbar. Boston, July 23. In Calendar of State Papers Colonial, America and West Indies, Volume 36, edited by Cecil Headlam and Arthur Percival Newton, 475-476. London: HMSO.

Dunbar, David. 1732. Letter to Mr. Popple Aug 25. In Calendar of State Papers Colonial, America and West Indies, Volume 39, edited by Cecil Headlam and Arthur Percival Newton, 199-203. London: HMSO.

Dunbar, David. 1734. Letter to Governor Belcher April 26. In Calendar of State Papers Colonial America and West Indies, Volume 41, edited by Arthur Percival Newton, 92-93. London: HMSO.

Ecclesiasticus 1996. Ecclesiasticus. In The Holy Bible, Conteyning the Old Testament, and the New: Newly Translated Out of the Originall Tongues: \& With the Former Translations Diligently Compared and Reuised by His Maiesties Speciall Comandement Appointed to Be Read in Churches, edited by Robert Barker et al. Cambridge: Chadwyck-Healey.

Edwards, Amy, and Richard Hurley. 1981. Prisons Over Two Centuries. In Home Office 1782-1982, edited by John Rawles. London: Home Office. Accessed January 17, 2012. http://www.nationalarchives.gov.uk/ERORecords/HO/421/2/prisons/prishist.htm

Elizabeth I. 1591. A Mynute of Letters of Like Ttenour to Lord Lieutenantes of the Counties Recorded 6 June at the Court at Greenwich. In Acts of the Privy Council of England, Volume 21, edited by John Roche Dasent, 174-175. London: HMSO.

Esdras. 1996. Esdras. In The Holy Bible, Conteyning the Old Testament, and the New: Newly Translated Out of the Originall Tongues: \& With the Former Translations Diligently Compared and Reuised by His Maiesties Speciall Comandement Appointed to Be Read in Churches, edited by Robert Barker et al. Cambridge: Chadwyck-Healey.

Esper, Thomas. 1965. The Replacement of the Longbow by Firearms in the English Army. Technology and Culture 6 (3): 382-393.

Fairbrother, E. H. 1914. "The Broad Arrow": The King's Mark. Notes and Queries s11-IX (234): 481-483.

Faraday, Michael. 1834. Experimental Researches in Electricity. Eighth Series. Philosophical Transactions of the Royal Society of London 124: 425-470.

Ford, Horace Alfred. 1856. Archery: its Theory and Practice. London: J. Buchanan.

Fox-Davies, Arthur Charles. 1909. A Complete Guide to Heraldry. London: T. C. and E. C. Jack.

Franklin, Benjamin. 1839. Letter to General Charles Lee. In The Works of Benjamin Franklin, edited by Jared Sparks, 169170. Boston: Hilliard, Gray, and Company.

Fuller, Gillian. 2002. The Arrow: Directional Semiotics: Wayfinding in Transit. Social Semiotics 12 (3): 231-244.

Gilbert, William. 1600. Guilielmi Gilberti Colcestrensis, Medici, Londinensis, De Magnete, Magneticisque Corporibus, et De Magno Magnete Tellure. London: Petrus Short.

Gill, Adrian Anthony. 2012. In a Field of Their Own. The Sunday Times Magazine. London. March 4, 50-55.

Gresham, Thomas. 1554. Letter to the Council Nov. 30. In Calendar of State Papers Foreign, Mary: 1553-1558, edited by William B. Turnbull, 141. London: Longman, Green, Longman \& Roberts.

Guillim, John. 1679. A Display of Heraldry Manifesting a More Easie Access to the Knowledge Thereof Than Hath Been Hitherto Published by Any. London: Francis Tyton, Henry Brome, Thomas Basset, Richard Chiswell, John Wright, and Thomas Sawbridge.

Guy, Henry. 1693. Attachment to a Letter to the Customs Commissioners May 30. In Calendar of Treasury Books, Volume 10, edited by William Arthur Shaw, 219. London: HMSO.

Hansard, George Agar. 1841. The Book of Archery. London: Henry G. Bohn.

Harris, C. S. 1914. "The Broad Arrow": The King's Mark. Notes and Queries s11-X (241): 114.

Hart, Christopher. 2009. Ploughmen, Peasants and Boys Aged 12: Unsung Heroes of the Carnage at Agincourt. Daily Mail, July 23. London.

Hastings, Thomas. 1831. The British Archer or, Tracts on Archery. London: R. Ackerman.

Hawkins, Edward. 1883. Catalogue of Prints and Drawings in the British Museum. Division I. Political and Personal Satires. Edited by F. G. Stephens. London: Trustees of the British Museum.

Heiser, Julie, and Barbara Tversky. 2006. Arrows in Comprehending and Producing Mechanical Diagrams. Cognitive Science 30 (3): 581-592.

Henry VIII. 1528. The Proclamacion Made and De[vised by the] Kynges Hyghnesse Our Soueraygne Lorde and His Honorable Counsaile. London: Richard Pynsonum.

Holinshed, Raphael. 1577. The Firste [Laste] Volume of the Chronicles of England, Scotlande, and Irelande. London: Iohn Hunne.

Irwin, Brian St George.1977. The Ordnance Survey: Roy's Legacy. The Geographical Journal 143 (1): 14-26. 
J.M. 1852. The Broad Arrow. Notes and Queries s1-118: 115-116.

Jakobson, Roman. 1981. Linguistics and Poetics. In Roman Jakobson Selected Writings, edited by Stephen Rudy, 18-51. The Hague: Mouton \& Co.

Johnes, Martin. 2004. Archery, Romance and Elite Culture in England and Wales, c.1780-1840. History 89 (294): $193-208$.

Klee, Paul. 1922. Wandbild aus dem Tempel der Sehnsucht $>$ dorthin $\rightarrow$. Watercolor and transferred printing ink on gesso on fabric (26.7 x $37.5 \mathrm{~cm}$.). New York: Metropolitan Museum of Art. Accessed August 16, 2012. http://www.wikipaintings.org/en/paul-klee/wall-painting-from-the-temple-of-longing-1922

Klee, Paul. 1972. Pedagogical Sketchbook, edited by Sibyl Moholy-Nagy. New York: Praeger.

Leibowitz, Shira, and Roald Hoffmann. 1991. Signs and Portents: No Parking in the Courtroom. Diacritics 21 (1): 2-23.

Leja, Michael. 2001. Eakins and Icons. The Art Bulletin 83 (3): 479-497.

Maryatt, Frederick. 1830. The King's Own. London: George Routledge \& Sons.

Mitchel, John. 1854. Jail Journal or Five Years in British Prisons. Dublin: James Corrigan.

Ministry of Defence (MoD). 1984. DEF STAN 05-34/2 Marking of Service Material. Glasgow: Directorate of Standardization, Ministry of Defence.

Monk, John. 2011. Signs and Signals. In Perspectives on Information, edited by Markus Ramage and David Chapman, 5164. New York: Routledge.

Moseley, Walter Michael. 1792. An Essay on Archery. London: J. Robson.

Murchison, Roderick Impey. 1861. Address to the Royal Geographical Society of London. Proceedings of the Royal Geographical Society of London 5 (4): 146-217.

P.C.S.S. 1851. Broad Arrow. Notes and Queries s1-IV (106): 371-372.

Paternoster, Raymond. 2010. How Much Do We Really Know About Criminal Deterrence? Journal Of Criminal Law \& Criminology 100 (3): 765-823.

Pepys, Samuel. 1926. Samuel Pepys Naval Minutes, edited by J.R. Tanner. London: Navy Records Society.

Prison Commission. 1922. Report of the Commissioners of Prisons and the Directors of Convict Prisons, With Appendices. London: HMSO.

R.S. 1596. A Briefe Treatise, to Proove the Necessitie and Excellence of the Use of Archerie. Holburne: Richard Johnes.

Ramblers. 2012. Footpath Law: Ramblers Charity. Accessed June 25, 2012. http://www.ramblers.org.uk/info/britain/footpathlaw/footpathlaw2

Renton, Edward H. 1889. Heraldry in England. London: Wyman \& Sons.

Richardson, James. 1848. Travels in the Great Desert of the Sahara in the years of 1845 and 1846. London: Richard Bentley.

Riley, Henry Thomas, ed. 1868. Memorials of London and London Life: In the 13th, 14th and 15th centuries. London: Longmans, Green \& Co.

Rosch, Eleanor, and Carolyn B. Mervis. 1975. Family Resemblances: Studies in the Internal Structure of Categories. Cognitive Psychology 7 (4), 573-605.

Sanders-Hewett, Timothy John Muirhead. 2004. Pip Sanders-Hewett. La Flèche (31): 10-11.

Sambourne, Edward Linley. 1910. Paid in His Own Coin. In Mr. Punch On the Warpath: Humours of the Army, the Navy and the Reserve Forces, edited by J. A. Hammerton, 13. London: The Educational Book Co.

Schott, G. D. 2000. Illustrating Cerebral Function: The Iconography of Arrows. Philosophical Transactions: Biological Sciences 355 (1404): 1789-1799.

Sherman, William H. 2005. Toward a History of the Manicule. London: Centre for Editing Lives and Letters. Accessed March 12, 2012. http://www.livesandletters.ac.uk/papers/FOR 200504 002.html

Smythe, John. 1590. Certain Discourses, Written by Sir John Smythe, Knight: Concerning the Formes and Effects of Divers Sorts of Weapons, and Other Verie Important Matters Militarie. Holburne Bridge: Richard Johnes.

Stone, George Cameron. 1934. A Glossary of the Construction, Decoration, and Use of Arms and Armor in All Countries and in All Times: Together with Some Closely Related Subjects. Portland, Maine: Southwork Press.

Stow, John. 1598. A Survay of London. London: John Wolfe.

Such, Augustus. 1841. Remarks On Prison Discipline and the Model Prison. London: Shaw \& Sons.

Suga, Yasuko. 2003. 'Purgatory of taste' or Projector of Industrial Britain? The British Institute of Industrial Art. Journal of Design History 16 (2): 167-185.

Surrency, Erwin C. 1967. The Courts in the American Colonies. The American Journal of Legal History 11(4): $347-376$.

Thompson, Maurice. 1877. Bow-Shooting. Scribner's Monthly 14 (3): 273-288.

Thompson, Maurice. 1878. The Witchery of Archery. New York: C. Scribner's sons.

Tolles, Frederick B. 1954. The American Revolution Considered as a Social Movement: A Re-Evaluation. The American Historical Review 60 (1): 1-12.

Tomalin, David J., Paul Simpson, and John M. Bingeman. 2000. Excavation Versus Sustainability in Situ: A Conclusion On 25 Years of Archaeological Investigations at Goose Rock, a Designated Historic Wreck-Site at the Needles, Isle of Wight, England. International Journal of Nautical Archaeology 29 (1): 3-42.

Tourney, Humphrey. 1633. Letter to Sec. Coke April 17. In Calendar of State Papers Domestic, Volume 237: Charles I, 1633-4, edited by John Bruce, 22-23. London: Longman, Green, Longman, Roberts and Green.

Treasury. 1696. Reference to the Excise Commissioners of the Petition of Antho Phillips July 30. In Calendar of Treasury Books, Volume 11: 1696-1697, edited by William Arthur Shaw, 222. London: HMSO.

Ward, C. A. 1884. Broad Arrow. Notes and Queries s6-X (247): 238-239.

Ward, Robert. 1639. Anima'Dversions of Warre; or, A Militarie Magazine of the Truest Rules, and Ablest Instructions, for the Managing of Warre. London: Francis Eglesfield.

Welch, Charles. 1902. History of the Worshipful Company of Pewterers of the City of London. Vol. I. London: Blades, East \& Blades.

Whittaker, Fewd, ed. 1880. Handbook of Summer Athletic Sports. New York: Beadle and Adams.

Wikström, Per-Olof H., Andromachi Tseloni, and Dimitris Karlis. 2011. Do People Comply With the Law Because They Fear Getting Caught? European Journal of Criminology 8 (5): 401-420. 
William and Mary. 1693. A Proclamation for the Preventing of the Stealth and Imbezilment of Their Majesties Stores of War. London: Charles Bill.

William and Mary. 1691. The Charter of the Province of Massachusets Bay in New England. In The Charter Granted By Their Majesties King William and Queen Mary, to the Inhabitants of the Province of the Massachusetts-Bay in NewEngland, 12. Boston: His Excellency the Governor, Council and House of Representatives.

Williams, Roger. 1590. A Briefe Discourse of Warre. Paternoster Row, London: Thomas Orwin.

Wither, Charles. 1722. Report to the Lords of the Treasury July 6. In Calendar of Treasury Papers, 1556-[1728]: 17201728, Volume 6, edited by Joseph Redington, 143. London: Longmans, Green, Reader, and Dyer. Wittgenstein, Ludwig. 1992. Philosophical Investigations. Oxford: Blackwell.

\section{About the Author}

John Monk

John Monk is a Chartered Engineer and Emeritus Professor of Digital Systems at the Open University with an interest in the lessons that can be learned from everyday uses of signs. He is a student of the philosophy of technology and is active in the assessment and registration of professional engineers. 